\title{
Daily transcriptome changes reveal the role of nitrogen in controlling microcystin synthesis and nutrient transport in the toxic cyanobacterium, Microcystis aeruginosa
}

Matthew J. Harke and Christopher J. Gobler

\begin{abstract}
Background: While transcriptomics have become a valuable tool for linking physiology and ecology in aquatic microbes, the temporal dynamics of global transcriptomic patterns in Microcystis have rarely been assessed. Furthermore, while many microbial studies have explored expression of nutrient transporter genes, few studies have concurrently measured nutrient assimilation rates. Here, we considered how the global transcriptomic patterns and physiology of the cyanobacterium, Microcystis aeruginosa, changed daily as cells were grown from replete to deficient nitrogen $(\mathrm{N})$ conditions and then back to replete conditions.

Results: During N deprivation, Microcystis downregulated genes involved in photosynthesis and respiration, carbon acquisition, lipid metabolism, and amino acid biosynthesis while upregulating genes involved in $\mathrm{N}$ acquisition and transport. With increasing $N$ stress, both the strength of expression and number of genes being differentially expressed increased, until $\mathrm{N}$ was restored at which point these patterns reversed. Uptake of ${ }^{15} \mathrm{~N}$-labeled nitrate, ammonium and urea reflected differential expression of genes encoding transporters for these nutrients, with Microcystis appearing to preferentially increase transcription of ammonium and urea transporters and uptake of these compounds during $\mathrm{N}$ deprivation. Nitrate uptake and nitrate transporter expression were correlated for one set of transporters but not another, indicating these were high and low affinity nitrate transporters, respectively. Concentrations of microcystin per cell decreased during $\mathrm{N}$ deprivation and increased upon $\mathrm{N}$ restoration. However, the transcript abundance of genes involved in the synthesis of this compound was complex, as microcystin synthetase genes involved in peptide synthesis were downregulated under $\mathrm{N}$ deprivation while genes involved in tailoring and transport were upregulated, suggesting modification of the microcystin molecule under $\mathrm{N}$ stress as well as potential alternative functions for these genes and/or this toxin.
\end{abstract}

Conclusions: Collectively, this study highlights the complex choreography of gene expression, cell physiology, and toxin synthesis that dynamic $\mathrm{N}$ levels can elicit in this ecologically important cyanobacterium. Differing expression patterns of genes within the microcystin synthetase operon in response to changing $\mathrm{N}$ levels revealed the potential limitations drawing conclusions based on only one gene in this operon.

Keywords: Microcystis, Transcriptome, Microcystin, Nitrogen

\footnotetext{
* Correspondence: christopher.gobler@stonybrook.edu

School of Marine and Atmospheric Sciences, Stony Brook University, 239

Montauk Hwy, Southampton, NY 11968, USA
} 


\section{Background}

The cyanobacterium Microcystis commonly forms blooms in temperate, freshwater ecosystems and can produce the hepatotoxin, microcystin. Toxic blooms of this species have led to beach closures, public water emergencies, and health concerns [1-3]. Anthropogenic nitrogen (N) loading can be an important factor in the occurrence of cyanobacteria blooms caused by non-diazotrophs such as Microcystis spp. [4-6]. For instance, field studies have demonstrated that $\mathrm{N}$ loading can promote blooms of Microcystis $[7,8]$ and toxic strains of Microcystis can outgrow non-toxic strains under high $\mathrm{N}$ levels $[6,9,10]$. There appears to be a link between $\mathrm{N}$ and microcystin production, whereby $\mathrm{N}$ deprived Microcystis cells display reduced transcription of microcystin synthetase genes and decreased microcystin content as compared to replete $\mathrm{N}$ cells [11]. This observation has been supported by culture studies [10, 12-15] and field studies that have found that increases in exogenous $\mathrm{N}$ concentrations have been associated with increases in microcystin in lakes $[5,11,13-16]$.

While the role of phosphorus in controlling the growth and physiology of freshwater cyanobacteria has been well studied $[17,18]$, comparatively less is known regarding responses to dynamic levels of N. During nitrogen stress, some cyanobacteria are known to initially induce systems for uptake of multiple N-containing compounds [11, 19] and $\mathrm{N}$ acquired through these transporters is then converted to ammonium and assimilated through the glutamine sythetase-glutamate synthetase cycle (GS-GOGAT). When exogenous $\mathrm{N}$ availability becomes too low to supply internal N demands, cyanobacteria may begin to rely on internal stores of $\mathrm{N}$ to prolong growth and may downregulate photosynthesis [20-22]. Still, freshwater cyanobacterial studies exploring physiological linkages between gene responses to $\mathrm{N}$ limitation and changes in cell physiology have been limited, especially for toxic, freshwater genera such as Microcystis.

Transcriptomics have become a valuable tool for investigating linkages between physiology and ecology in aquatic microbes. To date, most global transcriptomic studies have examined single time points or time series studies over a day/night cycle [11, 23-29] with the exception of limited microarray studies [22, 30]. In this study, we sought to document the daily global transcriptomic patterns of Microcystis aeruginosa over a one week period as cells were grown from replete to deficient $\mathrm{N}$ conditions and returned to replete conditions. To assess the choreography of gene expression and cell physiology we examined expression patterns of microcystin synthetase genes and genes relating to $\mathrm{N}$ transport, carbon acquisition, and photosynthesis in unison with levels of cellular microcystin and nutrients, as well as the uptake rate of nitrogenous compounds and bicarbonate. To our knowledge, the relationship between the expression of transporter genes and the uptake of corresponding target compounds (as measured here via isotopic tracers) has never been documented in cyanobacteria.

\section{Methods \\ Experimental design}

Experiments were conducted to track gene expression patterns of Microcystis aeruginosa as populations were grown from $\mathrm{N}$-replete conditions into low $\mathrm{N}$ conditions and returned to replete conditions. Experiments were performed with Microcystis aeruginosa clone LE-3 (Lake Erie, USA) [31] maintained in BG-11 medium illuminated by fluorescent lights that provided a light intensity of $\sim 100 \mu \mathrm{mol}$ quanta $\mathrm{m}^{-2} \mathrm{~s}^{-1}$ on a 14:10 light/dark cycle at $25{ }^{\circ} \mathrm{C}$. Treatments included $\mathrm{N}$ replete $(0.1 \mathrm{M}$ nitrate) cultures $(n=3)$ to serve as a control and a set of cultures that began with $50 \mu \mathrm{M}$ nitrate $(n=3)$. All cultures were inoculated into $2 \mathrm{~L}$ Erlenmeyer flasks containing $1 \mathrm{~L}$ media with $10^{6}$ cell $\mathrm{mL}^{-1}$ harvested from a replete culture by centrifugation $(2000 \times \mathrm{g}$ for $10 \mathrm{~min})$ [11] Cultures were monitored daily for cell density, in vivo chlorophyll a fluorescence, photosynthetic efficiency, total microcystin concentrations, ${ }^{15} \mathrm{~N}$ and ${ }^{13} \mathrm{C}$ uptake, and dissolved and total nutrient concentrations (see below for methods) at the same time daily to avoid diel changes in gene expression and cell physiology [32]. In addition, for transcriptomic sequencing, $50 \mathrm{~mL}$ aliquots of each replicate in each treatment were centrifuged for $10 \mathrm{~min}$. at $2000 \times \mathrm{g}$, immediately flash frozen in liquid $\mathrm{N}$, and stored at $-80{ }^{\circ} \mathrm{C}$. Cultures were grown semicontinuously; after each daily sampling, N-replete and $\mathrm{N}$-deplete cultures were diluted to $10^{6}$ cells $\mathrm{mL}^{-1}$ with BG-11 medium containing $0.1 \mathrm{M}$ nitrate or no $\mathrm{N}$, respectively, causing increasing $\mathrm{N}$ starvation in $\mathrm{N}$-deplete cultures. When photosynthetic efficiency was significantly depressed in the $\mathrm{N}$-deplete cultures after 5 days, a re-feed was conducted by adding in $25 \mu \mathrm{M}$ nitrate daily after samples were collected, a level commonly achieved in dynamic lake environments during blooms [7, 33], until the experiment ended on day 8 .

\section{Sample analysis}

Lugol's iodine preserved cells were enumerated using a

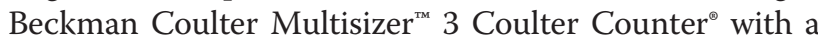
$50 \mu \mathrm{m}$ aperture which allowed cell densities to be quantified with a relative standard deviation of $3 \%$ [11]. Nitrate was analyzed by reducing the nitrate to nitrite using spongy cadmium as per Jones [34]. Ammonium and phosphate were analyzed using techniques modified from Parsons et al. [35]. Total dissolved N and P were analyzed using persulfate digestion techniques from Valderrama [36]. Urea was analyzed according to Price and Harrison [37]. These nutrient analyses provided $100 \pm$ $10 \%$ recovery of standard reference material (SPEX 
CertiPrep $\left.{ }^{\mathrm{m}}\right)$ for nitrate, ammonium, phosphate, total dissolved N, and total dissolved P. Whole water samples were analyzed for the hepatoxin microcystin by first freezing samples at $-20{ }^{\circ} \mathrm{C}$ for $24 \mathrm{~h}$ and then lysing the cells using an Abraxis QuikLyse ${ }^{\text {Tu }}$ Cell Lysis kit for Microcystins/Nodularins ELISA Microtiter Plate according to the manufacturer's instructions. Lysed samples were then analyzed with a colorimetric immunoassay using an Abraxis Microcystins/Nodularins (ADDA) ELISA Kit according to the manufacturer's instructions [38]. This method provided an analytical precision of $\pm 2 \%$ and a $96 \pm 2 \%$ recovery of spiked samples. Maximum quantum efficiency of photosystem II $\left(\mathrm{F}_{\mathrm{v}} / \mathrm{F}_{\mathrm{m}}\right)$ was estimated from in vivo $\left(\mathrm{F}_{\mathrm{i}}\right)$ and DCMU (3,4-dichlorophenyl-1,1-dimethylurea)-enhanced in vivo fluorescence $\left(\mathrm{F}_{\mathrm{m}}\right)$ of each replicate experimental sample on a Turner Designs TD-700 fluorometer (EM filter of $>665 \mathrm{~nm}$ and EX filter of 340-500 nm) using blank corrections from BG-11 media. Our prior research has demonstrated that $F_{v} / F_{m}$ is a sensitive diagnostic of $\mathrm{N}$-limitation in the strain of Microcystis studied here [11].

\section{Nitrogen and bicarbonate uptake}

Tracer experiments were conducted with ${ }^{15} \mathrm{~N}$ and ${ }^{13} \mathrm{C}$ to determine rates at which $\mathrm{N}$ - and C-containing compounds were being assimilated by Microcystis and assess the relationship between transcript abundance of specific transporters and actual uptake rates. Uptake rates of nitrate, ammonium, urea and bicarbonate were measured using additions of highly enriched (>98\%) ${ }^{15} \mathrm{~N}$-nitrate, ${ }^{15} \mathrm{~N}$-ammonium, ${ }^{15} \mathrm{~N}$-urea, and ${ }^{13} \mathrm{C}$-sodium bicarbonate [39]. Actual concentrations of nitrate, ammonium, and urea were measured as described above whereas levels of bicarbonate were calculated using the software program, CO2SYS (http://cdiac.ornl.gov/ftp/co2sys/) based on infrared analysis of total dissolved inorganic carbon with a PP Systems EGM-4 Environmental Gas Analyzer and $\mathrm{pH}$ measurements with an Orion Star $3 \mathrm{pH}$ meter. All isotope additions were $<10 \%$ of ambient concentrations. Incubations were performed in $50 \mathrm{ml}$ acid-washed polycarbonate flasks under the same light and temperature conditions used for semi-continuous cultures for $60 \mathrm{~min}$, after which water was filtered onto pre-combusted (2 h @ $\left.450{ }^{\circ} \mathrm{C}\right)$ EMD Millipore APFB glass fiber filters. Subsamples of the initial water sample were also filtered onto precombusted EMD Millipore APFB glass fiber filters to determine the natural abundance of ${ }^{15} \mathrm{~N}$ and ${ }^{13} \mathrm{C}$ within cells prior to enrichment. Filters were pelletized in tin discs and analyzed at the U.C. Davis Stable Isotope Facility (Davis, CA) using an Elementar vario Micro Cube elemental analyzer (Elementar Analysensysteme GmbH, Hanau, Germany) interfaced to a PDZ Europa 20-20 isotope ratio mass spectrometer (Sercon Ltd., Cheshire, UK). Uptake rates were calculated using equations from Orcutt et al.
[40]. Rates were considered net uptake as they were not corrected for the effects of isotope dilution [41]; however, uptake, release, and subsequent re-uptake of compounds during incubations was likely limited given the brief incubation period (60 $\mathrm{min})$.

\section{RNA isolation and sequencing}

RNA was extracted from triplicate biological replicate samples. A RNeasy Mini Kit with RNAprotect Bacteria reagent (QIAGEN) was used to isolate RNA in a similar manner to that outlined in Ilikchyan et al. [42]. Briefly, $2 \mathrm{~mL}$ of RNAprotect Bacteria reagent was added to cell pellets and gently vortexed to resuspend pelleted material. The mixture was then allowed to incubate for $5 \mathrm{~min}$. at room temperature and then centrifuged for $10 \mathrm{~min}$. at $2000 \times$ g. The supernatant was removed by pipet and then $200 \mu \mathrm{L}$ of TE buffer with lysozyme (SIGMA) and proteinase K (QIAGEN) was added. The pellet was resuspended by pipetting and allowed to incubate for $10 \mathrm{~min}$. at room temperature. The remainder of the RNeasy Mini Kit protocol was then followed according to the manufacturer's instructions. To remove any traces of contaminating genomic DNA, on-column DNase digestion was performed on RNA samples using RNasefree DNase (QIAGEN) according to the manufacturer's instructions. Ribosomal RNA was removed from total RNA $(\sim 3 \mu \mathrm{g})$ using an Epicenter ${ }^{\ominus}$ Ribo-Zero ${ }^{\text {Tm }}$ Magnetic Kit (Bacteria) according to the manufacturer's instructions. After rRNA depletion, samples were purified using a Qiagen RNeasy MinElute Cleanup Kit according to the instructions outlined by the Epicentre Ribo-Zero ${ }^{\mathrm{Tm}}$ Magnetic Kit. Post-digested RNA was assessed for quantity and quality with an Agilent Bioanalyzer ${ }^{\text {max }}$ (RNA Integrity $>9.5$ for all samples). Samples were stored at $-80{ }^{\circ} \mathrm{C}$ until sequencing. Sequencing libraries were prepared using a TruSeq ${ }^{\mathrm{mm}}$ RNA Sample Preparation Kit v2 (Illumina ${ }^{\circ}$ ) according to the manufacturer's instructions, skipping the poly-A pull-down step. Library prep and sequencing of $100 \mathrm{bp}$ single-end reads per library was performed by the JP Sulzberger Columbia Genome Center (New York, NY) on an Illumina ${ }^{\circ}$ HiSeq 2000 system. The Illumina ${ }^{\circ}$ sequences reported in this paper have been deposited in the National Center for Biotechnology Information's Sequence Read Archive (accession no. SRP056420).

\section{Read mapping and analysis}

Prior to read mapping, raw reads were initially characterized with FastQC (http:// http://www.bioinformatics.bbsrc.ac.uk/projects/fastqc/) and were trimmed to remove ambiguous and low quality reads with Trimmomatic v0.32 [43]. Surviving reads were mapped to the reference genome Microcystis aeruginosa NIES-843 [44] using RSEM v1.2.19 [45] with Bowtie 2 [46] with 
parameters recommend by the RSEM authors. Differential expression between the treatment and reference condition was computed with EBseq [47] within RSEM. Comparisons were accepted as significant with false discovery rate (FDR) controlled at 0.05 (in EBseq PPDE $\geq$ 0.95). Differentially expressed genes were assigned functional categories based upon categories found in CyanoBase for the Microcystis NIES-843 genome (http:// genome.microbedb .jp/cyanobase/Microcystis). The blastp suite (http://blast.ncbi.nlm.nih.gov) and CombFunc [48] were used to elucidate putative functions of hypothetical genes using an E-value cutoff of $1 \mathrm{e}^{-5}$.

\section{Statistical analysis}

Differences in photosynthetic efficiency, cellular chlorophyll, and total microcystins between the control and low $\mathrm{N}$ treatment were analyzed using two-way repeatedmeasures ANOVAs (ANOVARs). Each experimental flask was considered a subject for these analyses and factors were nutrient condition (control or low N) and time. Post hoc comparisons were conducted with the Holm-Sidak method. Correlations between transcript abundance ( $\log _{2}$ fold change) and uptake of $\mathrm{C}$ and $\mathrm{N}$ compounds were calculated using a Spearman Rank Correlation coefficient. All statistical analysis were conducted in SigmaPlot version 11.0 Build 11.1.0.102 and statistical results were considered significant at an $\alpha$ $<0.05$.

\section{Results}

\section{Differential growth among treatments}

Multiple characteristics of Microcystis cultures changed as they grew in the absence of $\mathrm{N}$. Although the low $\mathrm{N}$ culture began with $50 \mu \mathrm{M}$ nitrate and $19 \mu \mathrm{M}$ ammonium, concentrations were reduced to $<1 \mu \mathrm{M}$ by 24 and $48 \mathrm{~h}$, respectively, and remained at this level until the re-addition of nitrate (day 5) when nitrate concentrations exceeded $7 \mu \mathrm{M}$ but ammonium remained $<1 \mu \mathrm{M}$ (Table 1A, B). Urea concentrations were at or near sub-micromolar concentrations throughout the experiment (Table 1C). While photosynthetic efficiency $\left(\mathrm{F}_{\mathrm{v}} / \mathrm{F}_{\mathrm{m}}\right)$ remained elevated in control cultures during the experiment $(0.47 \pm 0.2)$, it declined in the low $\mathrm{N}$ treatment and was significantly lower than the control on days 3-7 $(p<0.001$, twoway ANOVAR), reaching $0.38 \pm 0.04$ on day 5 after which nutrients were added (Fig. 1a). $F_{v} / F_{m}$ was unchanged on day 6 but recovered thereafter matching the control cultures by day $8(0.49 \pm 0.04$; Fig. 1a). Cellular chlorophyll $a$ displayed a similar patterns being unchanged in control cultures throughout the experiment $\left(0.19 \pm 0.03 \mathrm{ng}\right.$ chla cell ${ }^{-1}$; Fig. 1b) but significantly declining to a minimum of $0.06 \pm 0.00 \mathrm{ng}$ chla cell $^{-1}$ in low N cultures $(p<0.001$, two-way ANOVAR, Fig. 1b). Upon
Table 1 Nutrient concentrations during the experiment

\begin{tabular}{|c|c|c|}
\hline Timepoint & Replete & $50 \mu \mathrm{M}$ Nitrate \\
\hline \multicolumn{3}{|l|}{$\bar{A}$} \\
\hline 0 & $12,410(949)$ & $11.81(2.52)$ \\
\hline 1 & $13,097(148)$ & $7.90(4.20)$ \\
\hline 2 & $12,734(478)$ & $0.54(0.00)$ \\
\hline 3 & $12,917(40)$ & $\mathrm{BDL}$ \\
\hline 4 & $13,612(976)$ & $\mathrm{BDL}$ \\
\hline 5 & $14,607(38)$ & $\mathrm{BDL}$ \\
\hline 6 & $13,517(1330)$ & $0.25(0.00)$ \\
\hline 7 & $11,863(2032)$ & $1.76(0.00)$ \\
\hline 8 & 13,791 (138) & $7.49(0.00)$ \\
\hline \multicolumn{3}{|l|}{ B } \\
\hline 0 & $23.06(4.18)$ & $19.04(3.00)$ \\
\hline 1 & $0.41(0.10)$ & $0.71(0.18)$ \\
\hline 2 & $0.52(0.02)$ & $0.55(0.09)$ \\
\hline 3 & $0.40(0.01)$ & $0.68(0.32)$ \\
\hline 4 & $0.49(0.10)$ & $0.74(0.19)$ \\
\hline 5 & $0.60(0.14)$ & $0.80(0.09)$ \\
\hline 6 & $0.42(0.03)$ & $0.89(0.35)$ \\
\hline 7 & $0.49(0.11)$ & $0.56(0.35)$ \\
\hline 8 & $0.64(0.57)$ & $0.80(0.31)$ \\
\hline \multicolumn{3}{|l|}{ C } \\
\hline 0 & $1.15(0.53)$ & $0.21(0.13)$ \\
\hline 1 & N/A & $0.38(0.15)$ \\
\hline 2 & N/A & $0.26(0.10)$ \\
\hline 3 & N/A & $0.19(0.19)$ \\
\hline 4 & N/A & $0.24(0.17)$ \\
\hline 5 & N/A & $0.42(0.15)$ \\
\hline 6 & N/A & $0.36(0.24)$ \\
\hline 7 & N/A & $0.27(0.26)$ \\
\hline 8 & $0.90(0.14)$ & $0.17(0.09)$ \\
\hline
\end{tabular}

Concentrations $(\mu \mathrm{M})$ of nitrate $(\mathrm{A})$, ammonium $(\mathrm{B})$, and urea $(\mathrm{C})$ during the experiment. Values in parenthesis are the standard deviation between biological replicates $(n=3)$. BDL denotes values below detection limit. N/A denotes not measured

restoration of $\mathrm{N}$ to the low $\mathrm{N}$ culture (day 5) cellular chlorophyll $a$ began to recover $\left(0.11 \pm 0.01 \mathrm{ng}\right.$ chla cell ${ }^{-1}$; Fig. 1b). Total microcystin concentrations were similar throughout the experiment in the control whereas in the low $\mathrm{N}$ treatments, concentrations of microcystin declined two-fold from $0.12 \pm 0.03 \mathrm{pg}$ MC-LR equivalents cell ${ }^{-1}$ to $0.06 \pm 0.01 \mathrm{pg}$ MC-LR equivalents cell ${ }^{-1}$ on day $5(p<0.001$, two-way ANOVAR; Fig. 1c). When $\mathrm{N}$ was restored (day 5), microcystin levels recovered to concentrations similar to the control cultures and were statistically greater on days 7 and 8 relative to day $5 \quad(p<0.001$, two-way ANOVAR, Fig. 1c). 

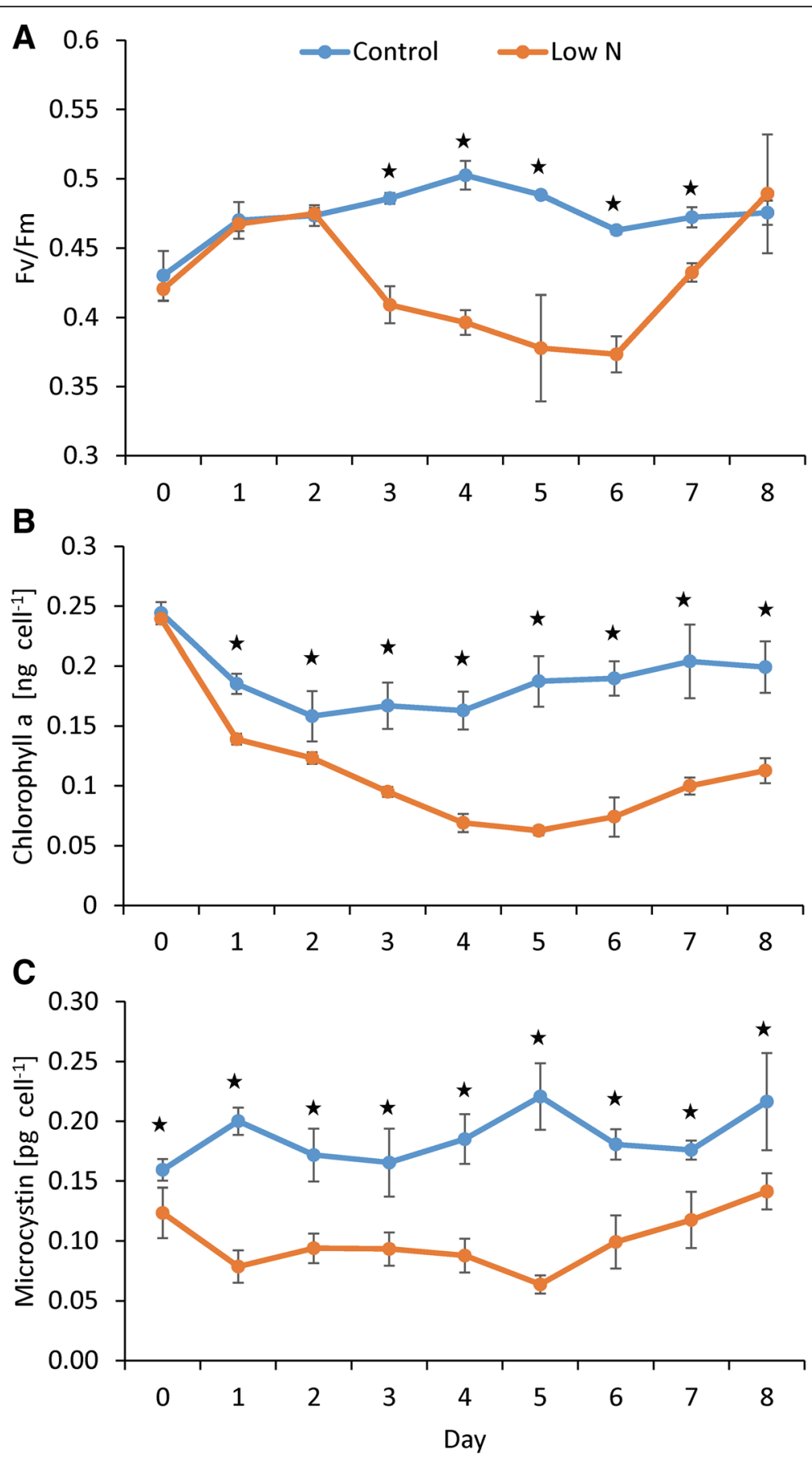

Fig. 1 Photosynthetic efficiency, chlorophyll, and microcystin trends during the experiment. Photosynthetic efficiency (a), total chlorophyll $a$ (b) and microcystin (MC-LR equivalents) concentrations per cell (c) during the experiment. Nitrogen refeed occurred on day 5. Error bars represent the standard deviation between biological replicates $(n=3)$. Stars indicate significant differences between treatments $(p<0.001$, two-way ANOVAR)

\section{Transcriptomic sequencing}

Transcriptomic sequencing yielded on average 38 million 100 bp reads per sample (Additional file 1: Table S1). Prior to generating read counts, Trimmomatic was run to remove ambiguous and low quality reads resulting in the removal of, on average, $5.25 \%$ of reads per sample. Of the surviving reads, $\sim 60 \%$ aligned to the reference genome (Microcystis aeruginosa NIES-843) with the highest alignment rates occurring on day 2 (87\%; Additional file 1: Table S1). Between 282 and 2512 genes were significantly differentially expressed daily in low $\mathrm{N}$ cultures, with the highest number of genes expressed 
during $\mathrm{N}$ limitation (days 2-5, Additional file 2: Figure $\mathrm{S} 1$ ). After restoration of $\mathrm{N}$ (on day 5), the number of differentially expressed genes decreased by $57 \%$ (Additional file 2: Figure $\mathrm{S} 1$ ). Of the differentially expressed genes, between 1 and $9 \%$ displayed $\log _{2}$ fold change greater than two with the largest number of these highly expressed genes occurring at the time of strongest $\mathrm{N}$ limitation $(9 \%$, day 5 , lowest photosynthetic efficiency, chlorophyll $a$ per cell; Additional file 2: Figure S1).
Within low $\mathrm{N}$ cultures, there was a $>50 \%$ increase in the number of genes that were differentially expressed in all functional categories of genes (as defined by Cyanobase; http://genome.microbedb.jp/cyanobase/) with the exception of genes with unknown function which only increased by $10 \%$ by day 2 (Additional file 3: Figure S2). The largest fraction of genes responding on a categorical level were genes within the "fatty acid, phospholipid and sterol

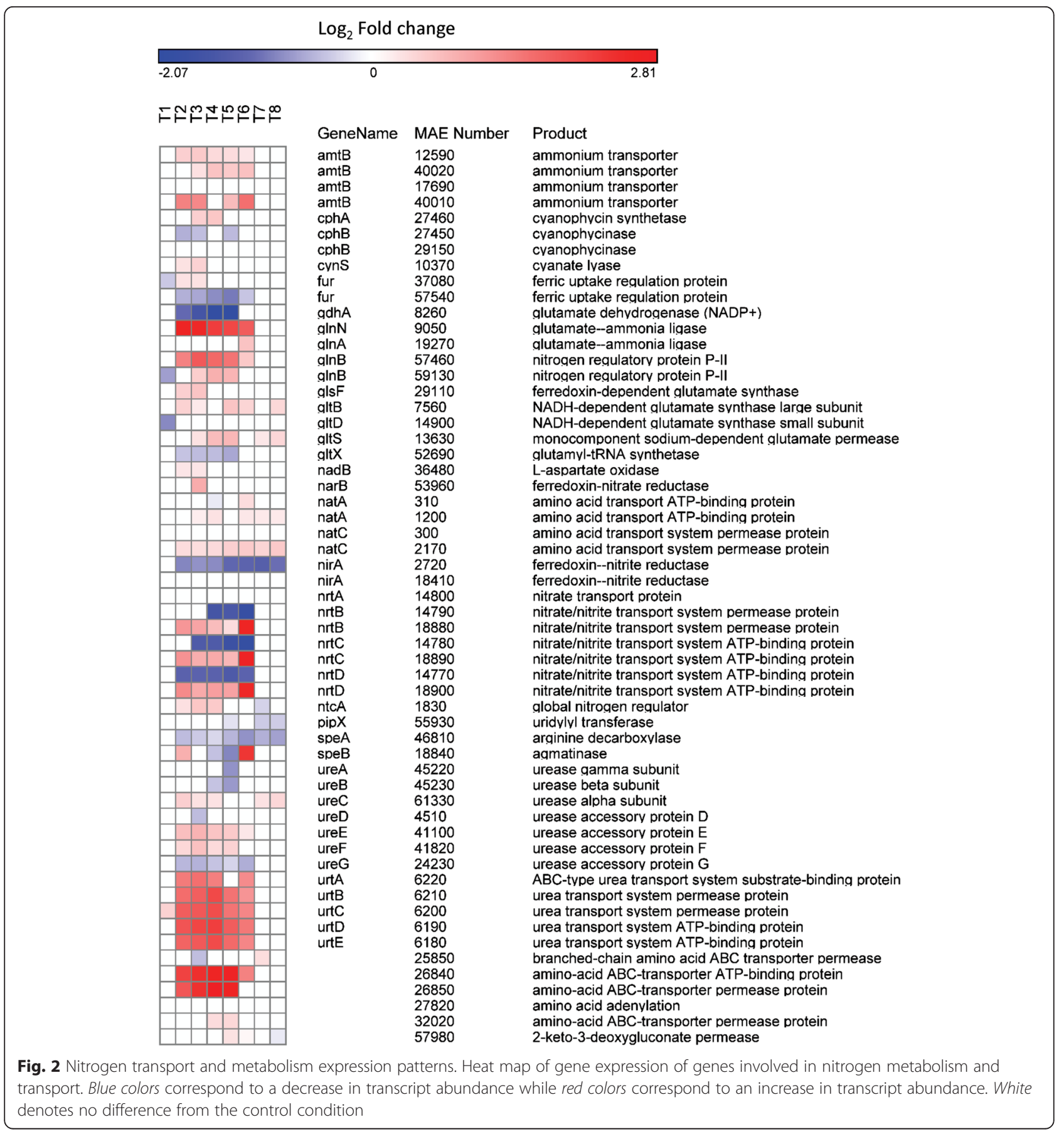


metabolism" functional grouping where the proportion of differentially expressed genes increased from $23 \%$ on day 1 to $93 \%$ of genes by day 3 of the experiment (Additional file 3: Figure S2). The smallest fraction of genes responding on a categorical level were genes within the "unknown" functional category (Additional file 3: Figure S2).

\section{Nitrogen metabolism}

As cells became $\mathrm{N}$-limited, many genes involved in $\mathrm{N}$ metabolism and assimilation were differentially expressed. For instance, the global nitrogen regulatory gene $n t c A$ increased in transcript abundance beginning on day 2 and peaked on day 4 (0.58 $\log _{2}$ fold change). After restoration of $\mathrm{N}$, differential expression was not detected again until day 7 where it was downregulated by 0.31 fold (Fig. 2). Other regulatory genes including the nitrogen regulatory $\mathrm{P}_{\mathrm{II}}$ genes $(g \ln B)$ and the pip $X$ gene were also differentially expressed during $\mathrm{N}$ limitation (Fig. 2). Microcystis has two $g \ln B$ genes (MAE57460 and 59130) and each was upregulated after day 2 with expression disappearing after day 5 or 6 depending on the gene (Fig. 2). The gene encoding pipX (MAE55930) was unchanged under $\mathrm{N}$ limitation but decreased in transcript abundance when $\mathrm{N}$ was restored on days 5,7 and 8 (Fig. 2).

Transcript abundance of genes involved in ammonium, nitrate/nitrite, amino acid and urea transport and metabolism paralleled those of nitrogen regulatory genes with increases in transcript abundance starting on day 2 and a return to similar transcript levels to the control after day 6 (one day after $\mathrm{N}$ restoration; Fig. 2). A more complicated response was observed for some gene sets with multiple copies. For instance, only one set of nitrate/nitrite transport systems was upregulated by $\mathrm{N}$ limitation (nrtBCD; MAE18880, 18890, 18900) while the other was downregulated (nrtBCD; MAE14770, 14780, 14790; Fig. 2). Furthermore, of the two nitrite reductases (nirA, MAE02720 and MAE18410), one was downregulated while the other displayed no change in expression relative to the control (Fig. 2). Of note, the nitrate/nitrite transporters that were upregulated under $\mathrm{N}$ limitation displayed even higher upregulation $24 \mathrm{~h}$ after nitrate was added ( $>2.5 \log _{2}$ fold change, day 6) compared to previous days $\left(<1.5 \log _{2}\right.$ fold change, Fig. 2). Finally, the gene involved in synthesis of the $\mathrm{N}$ storage product cyanophy$\operatorname{cin}(c p h A$, MAE27460) was upregulated on days 3 and 4 while the gene involved in the breakdown of this product (cyanophycinase, $c p h B$, MAE27450) was downregulated on days 2, 3, and 5 (Fig. 2).

\section{Microcystin synthetase}

Genes involved in microcystin synthesis displayed a bifurcated response to decreasing $\mathrm{N}$ levels. Genes involved in tailoring and transport (mcyHIJ) had increased transcript abundance during $\mathrm{N}$ deprivation whereas genes involved in peptide synthesis $(m c y A C D E)$ had decreased transcript abundance (Fig. 3). After $\mathrm{N}$ restoration, gene expression levels (except $m c y A$ which remained downregulated) became similar to control conditions in $24-48$ h until day 8 when expression of $m c y C D$ again decreased relative to the control. Differential expression of $m c y B$ and $m c y F$ was not detected. In contrast to the peptide synthetase genes (mcyACDE), as cells became more $\mathrm{N}$ limited, the microcystin tailoring and transport genes $m c y I$ and $m c y J$ increased in expression from $0.32 \log _{2}$ fold change on day 1 to $0.80 \log 2$ fold change on day 4 . When $\mathrm{N}$ was restored on day 5 , expression decreased and became similar to control values by day 7 (Fig. 3).

\section{Photosynthesis \& respiration}

When $\mathrm{N}$ was depleted by cultures (day 2, Table 1), $>50 \%$ of the genes involved in photosynthesis and respiration decreased in transcript abundance (Fig. 4). The number of genes and the magnitude of downregulation of these genes generally increased as cells progressed further into $\mathrm{N}$ limitation, peaking on day 5 (Fig. 4). After $\mathrm{N}$ restoration, expression of most of these genes was similar to the control condition (no differential expression) while a few began to increase in transcript abundance. Genes encoding cytochrome cM (MAE07790), protoheme IX farnesyltransferase (MAE22910), glyceraldehyde 3-phosphate dehydrogenase (MAE34890), pyruvate-flavodoxin oxidoreductase (MAE38140), two phycocyanin subunits (MAE51670 and 51680) and the phycobilisome degradation gene $n b l A$ (MAE02520) increased in transcript abundance starting on day 2 and then briefly returned to control values after $\mathrm{N}$ was restored (Fig. 4).

\section{Carbon concentration and transport}

More than $70 \%$ of genes involved in carbon concentration and transport were downregulated beginning on day 2 with the exception of two sodium/proton antiporters (MAE55560 and 60970) and one sodium-dependent bicarbonate transporter (MAE59140) which were upregulated (Fig. 5). After $\mathrm{N}$ was restored, expression of many of these genes was similar to control values and on day 7 , five genes were upregulated, including genes comprising a bicarbonate uptake system and a gene encoding a periplasmic carbonic anhydrase (ecaB, MAE15130; Fig. 5).

\section{Fatty acid, phospholipid and sterol metabolism}

More than $65 \%$ of genes involved in fatty acid, phospholipid, and sterol metabolism decreased in transcript abundance as cells became $\mathrm{N}$ limited and when $\mathrm{N}$ was restored, gene expression was similar to control conditions (Additional file 4: Figure S3). Contrary to this 

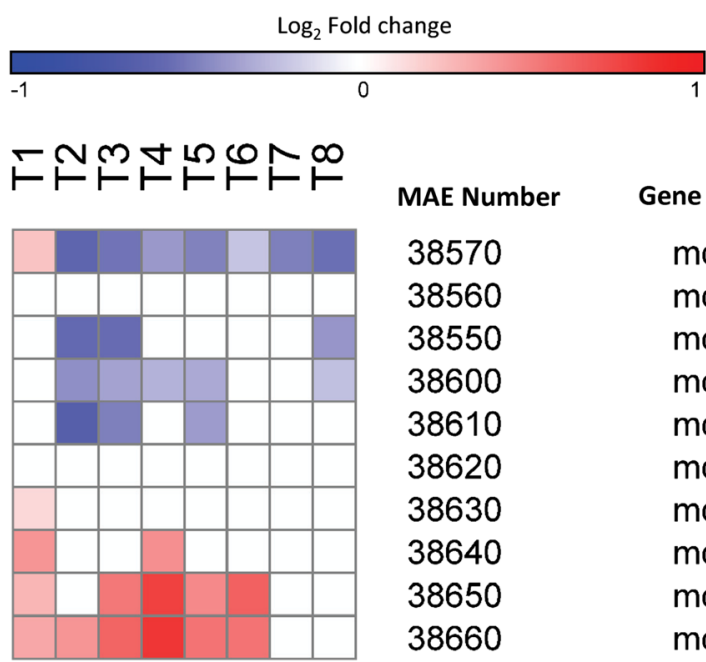

MAE Number
38570
38560
38550
38600
38610
38620
38630
38640
38650
38660

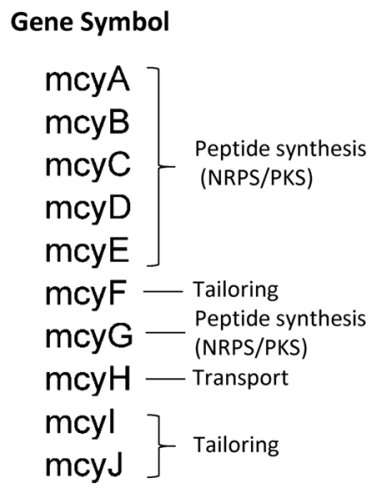

Fig. 3 Microcystin synthetase gene expression patterns. Heat map of gene expression of genes responsible for microcystin synthetase. Blue colors correspond to a decrease in transcript abundance while red colors correspond to an increase in transcript abundance. White denotes no difference from the control condition

pattern, a gene involved in lipid metabolism (MAE29450) which bears similarity to a fatty acid hydroxylase had large increases in transcript abundance during $\mathrm{N}$ deprivation (2.31 $\pm 0.24 \log _{2}$ fold change on days 2-5; Additional file 4: Figure S3). In addition, seven other genes increased in transcript abundance during $\mathrm{N}$ deprivation including genes encoding membrane bound enzymes (MAE55360), fatty acid catabolism (MAE50060), glycerolipid metabolism (MAE39670 and 25770), and transferases (MAE24880 and 13400). Many of these genes returned to control conditions 24 to $48 \mathrm{~h}$ after $\mathrm{N}$ was restored (Additional file 4: Figure S3).

\section{${ }^{15} \mathrm{~N}$ and ${ }^{13} \mathrm{C}$ uptake}

Uptake of nitrogenous compounds varied both between $\mathrm{N}$ compounds (nitrate, ammonium, and urea) and with time and generally matched expression patterns of associated $\mathrm{N}$-specific transporters. For instance, uptake rates of nitrate were static on days $1-5$ (averaging $3.34 \pm 0.91 \times 10^{-3}$ $\mathrm{hr}^{-1}$ ) but increased six-fold after $\mathrm{N}$ restoration on day 6 to $2.04 \pm 1.11 \times 10^{-2} \mathrm{hr}^{-1}$ (Fig. 6a). Similarly, a nitrate/nitrite transporter gene set $(n r t B C D)$ was upregulated by $0.95 \pm$ $0.24 \log _{2}$ fold change during days $2-5$ but increased by three-fold to $2.62 \pm 0.07 \log _{2}$ fold change on day 6 after nitrate was added (Fig. 6b). Uptake rates of nitrate and expression of these nitrate/nitrite transporters were highly correlated ( $p<0.001$; Fig. $6 \mathrm{a}, \mathrm{b})$. In contrast, another set of these nitrate/nitrite transporters ( $n r t B C D$, MAE14790, $14780,14770)$ was downregulated when nitrate levels decreased (Fig. 6c). Uptake rates of ammonium and urea increased as cultures became more $\mathrm{N}$ limited but decreased once $\mathrm{N}$ was restored (Figs. 7a and $8 \mathrm{a}$ ) and ammonium and urea transporters (amt and $u r t A B C D E$, respectively) were upregulated during $\mathrm{N}$ limitation, but returned to control levels once $\mathrm{N}$ was restored (Figs. $7 \mathrm{~b}$ and $8 \mathrm{~b}$ ). Ammonium and urea uptake constituted an increasing percentage of overall $\mathrm{N}$ uptake during $\mathrm{N}$ limitation, from $72 \%$ of uptake to $94 \%$ of uptake by day 5 . After nitrate was restored, nitrate constituted half of the total measured $\mathrm{N}$ uptake ( $47 \%$ on day 6; Additional file 5: Figure S4). Bicarbonate uptake decreased as cultures became more $\mathrm{N}$ limited and increased once $\mathrm{N}$ was restored (Fig. 9a). Expression patterns of genes within the bicarbonate uptake system (MAE62080, bicA; MAE62090, sbtA; MAE62100, sbtB; and MAE62110, nhaS3) [49] mirrored uptake patterns with gene expression downregulated on days 2-5 (Fig. 9b) but upregulated on day 7 (Fig. 9b) as uptake increased (Fig. 9a). As with nitrate uptake, uptake of bicarbonate and expression of the bicarbonate transporter gene set were highly correlated during this study ( $p<0.001$, Fig. 9).

\section{Discussion}

During $\mathrm{N}$ deprivation, cyanobacterial cells undergo numerous physiological changes including chlorosis [50], increased uptake of alternative forms of $\mathrm{N}$, and an increased reliance upon internal stores of C \& $N$ [51]. There is also a reduction in total protein synthesis, although proteins required for acclimation to nutrient stress may be upregulated $[51,52]$. Furthermore, there is evidence that $\mathrm{N}$-starved Microcystis cells decrease their cellular concentrations of microcystin [11, 14, 15] and decrease expression of genes responsible for synthetase of this toxin [11]. Here we sought to build on these prior observations by documenting the daily, global transcriptional patterns of Microcystis aeruginosa as well as $\mathrm{N}$ 


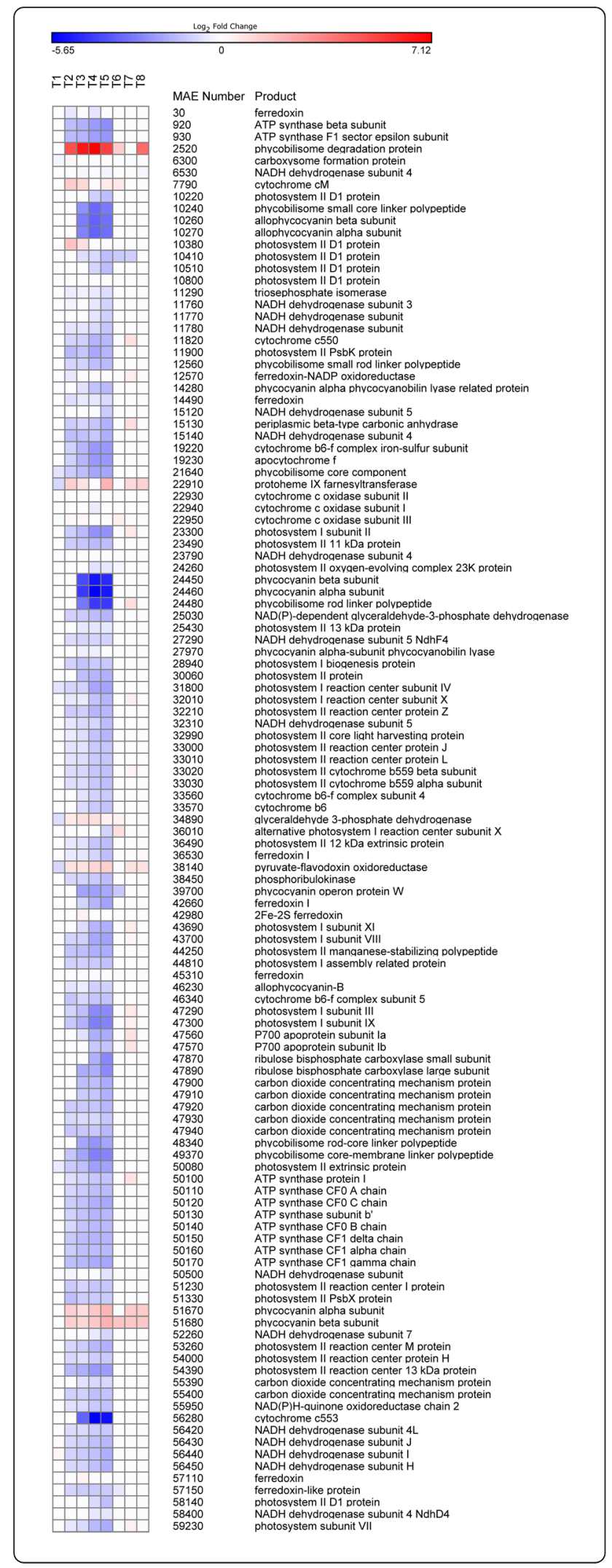

Fig. 4 Photosynthesis and respiration gene expression patterns. Heat map of gene expression of genes involved in photosynthesis and respiration. Blue colors correspond to a decrease in transcript abundance while red colors correspond to an increase in transcript abundance. White denotes no difference from the control condition

and bicarbonate uptake rates as cells entered and exited an $\mathrm{N}$ deprived state.

Cultures of Microcystis aeruginosa LE-3 exposed to low $\mathrm{N}$ conditions rapidly drew down external concentrations of nitrate (from $50 \mu \mathrm{M}$ initial concentrations to $<1 \mu \mathrm{M}$ by day 2 , Table 1 ) and exhibited multiple physiological characteristics of $\mathrm{N}$ limitation, including lower photosynthetic efficiency and cellular chlorophyll $a$ content (Fig. 1) [20, 50, 51]. In parallel, numerous genes involved in $\mathrm{N}$ acquisition and transport increased in transcript abundance (Fig. 2), while genes encoding photosynthesis and respiration, carbon acquisition, lipid metabolism, and amino acid biosynthesis decreased in transcript abundance (Figs. 4, 5 and Additional file 4: Figure S3). During $\mathrm{N}$ deprivation, cyanobacteria may rely on reserve materials to meet cellular demand, including photosynthetic pigments, lipids, and the $\mathrm{N}$ storage product cyanophycin $[51,53]$. Consistent with this, as Microcystis cells became more $\mathrm{N}$ limited, the gene encoding a phycobilisome degradation protein was increasingly upregulated ( $n b l A$, MAE02520) and photosynthetic efficiency declined, a result observed in other cyanobacteria $[54,55]$. Previous research has indicated that cyanophycin levels are generally low in rapidly growing cells but increase when nitrogen-deficient cyanobacteria are exposed to $\mathrm{N}$ excess or when cells are starved for light, phosphorus, or sulfur [53, 56, 57]. In this study, the expression of genes involved in the breakdown (MAE29150, cphB) and synthesis (MAE27490, $c p h A)$ of cyanophycin suggested that during $\mathrm{N}$ deprivation Microcystis was synthesizing cyanophycin (upregulation of $\operatorname{cph} A$ on days 3 and 4) and not degrading it (downregulation of $c p h B$ ). Cyanophycin has been shown to be synthesized during declining $\mathrm{N}$ conditions in Anabaena cylindrica and Synechocystis 6308 but completely consumed when all exogenous $\mathrm{N}$ was depleted by these cyanobacteria [58]. As suggested by these authors, cyanophycin may act as a dynamic $\mathrm{N}$ reservoir in cyanobacteria, including Microcystis, allowing cells to balance internal demand with changing external supplies of $\mathrm{N}$.

Lipids can be divided into two main groups: nonpolar (acylglycerols, sterols, fatty acids) and polar lipids (phosphogylcerides, gylcosylglycerides) [59]. Polar lipids and sterols are important structural components of cell membranes while nonpolar lipids can be important for energy storage and therefore play an important role in tolerance and survival of organisms to a variety of stressors, including $\mathrm{N}$ deprivation $[59,60]$. During $\mathrm{N}$ 

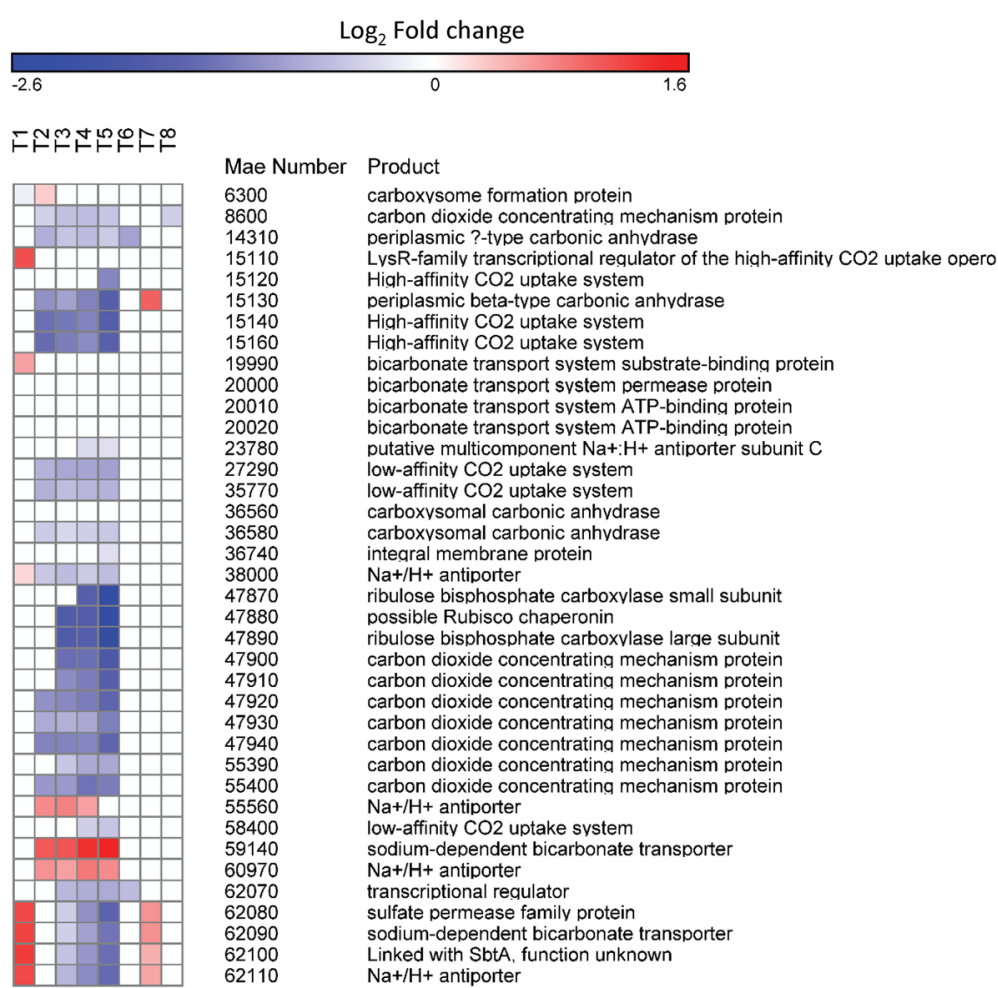

Fig. 5 Carbon concentration and transport gene expression patterns. Heat map of gene expression of genes involved in carbon concentration and transport. Blue colors correspond to a decrease in transcript abundance while red colors correspond to an increase in transcript abundance. White denotes no difference from the control condition

stress, cyanobacteria appear to reduce lipid and fatty acid inventories, but not composition [61-63]. Reduced lipid content under $\mathrm{N}$ stress is likely attributed to degradation of thylakoid membranes during the breakdown of the photosynthetic apparatus, which has been observed in numerous cyanobacteria [56, 63, 64]. Although lipid inventories were not quantified in this study, many of the genes involved in lipid and fatty acid metabolism were downregulated, suggesting lipid production was halted. However, some genes in the fatty acid, phospholipid, and sterol metabolism functional group were upregulated suggesting a more complex response $\mathrm{N}$ stress. For instance, a gene encoding a putative sterol C5desaturase (MAE 29450) had increased transcript abundance during $\mathrm{N}$ stress. Sterol desaturases are thought to be involved in sterol biosynthesis [65], however there is still much debate as to whether cyanobacteria produce sterols (a common component of eukaryotic membranes), despite many sequenced genomes contain genes that closely match at a sequence level to sterol biosynthesis genes [66]. Further, a gene encoding diacylglycerol kinase (MAE 39670), thought to act as signaling compound with involvement of regulating lipid metabolism [67], was also upregulated. Clearly, $\mathrm{N}$ stress elicits a complex response at the cellular level, with potential loss and rearrangement of membrane structures.
During this study, the responses of different gene groups to the restoration of $\mathrm{N}$ differed. Nearly every photosynthetic gene that was downregulated on day 5 (the peak of $\mathrm{N}$-deficiency as defined by photosynthetic efficiency) was expressed at normal levels $24 \mathrm{~h}$ after $\mathrm{N}$ had been restored. In contrast, most of the $\mathrm{N}$ metabolism genes, including the transporters of nitrogenous nutrients, were differentially expressed until day 7, nearly $48 \mathrm{~h}$ after $\mathrm{N}$ restoration began. Similar patterns were observed in the uptake of nitrate. While it is possible that an environmentally unrealistic, larger addition of $\mathrm{N}$ may have elicited a swifter change in the expression of $\mathrm{N}$ transporters, the $25 \mu \mathrm{M}$ nitrate added was enough to return expression of most photosynthetic genes to levels similar to the control in less than $24 \mathrm{~h}$ and thus indicates the different physiological responses of these two gene groups in Microcystis. This rapid recovery of photosynthesis has been observed in other cyanobacteria at a physiological and genetic level $[30,56]$. Indicators of photosynthetic activity including photosynthetic efficiency $\left(\mathrm{F}_{\mathrm{v}} / \mathrm{F}_{\mathrm{m}}\right)$, chlorophyll $a$ content per cell, and uptake of bicarbonate were largely unchanged until $48 \mathrm{~h}$ after $\mathrm{N}$ restoration evidencing a $24 \mathrm{~h}$ lag between altered gene expression and protein synthesis and/or physiological response. Krasikov et al. [30] similarly reported that $\mathrm{N}$ transporter genes in Synechocystis recovered 6-12 h 


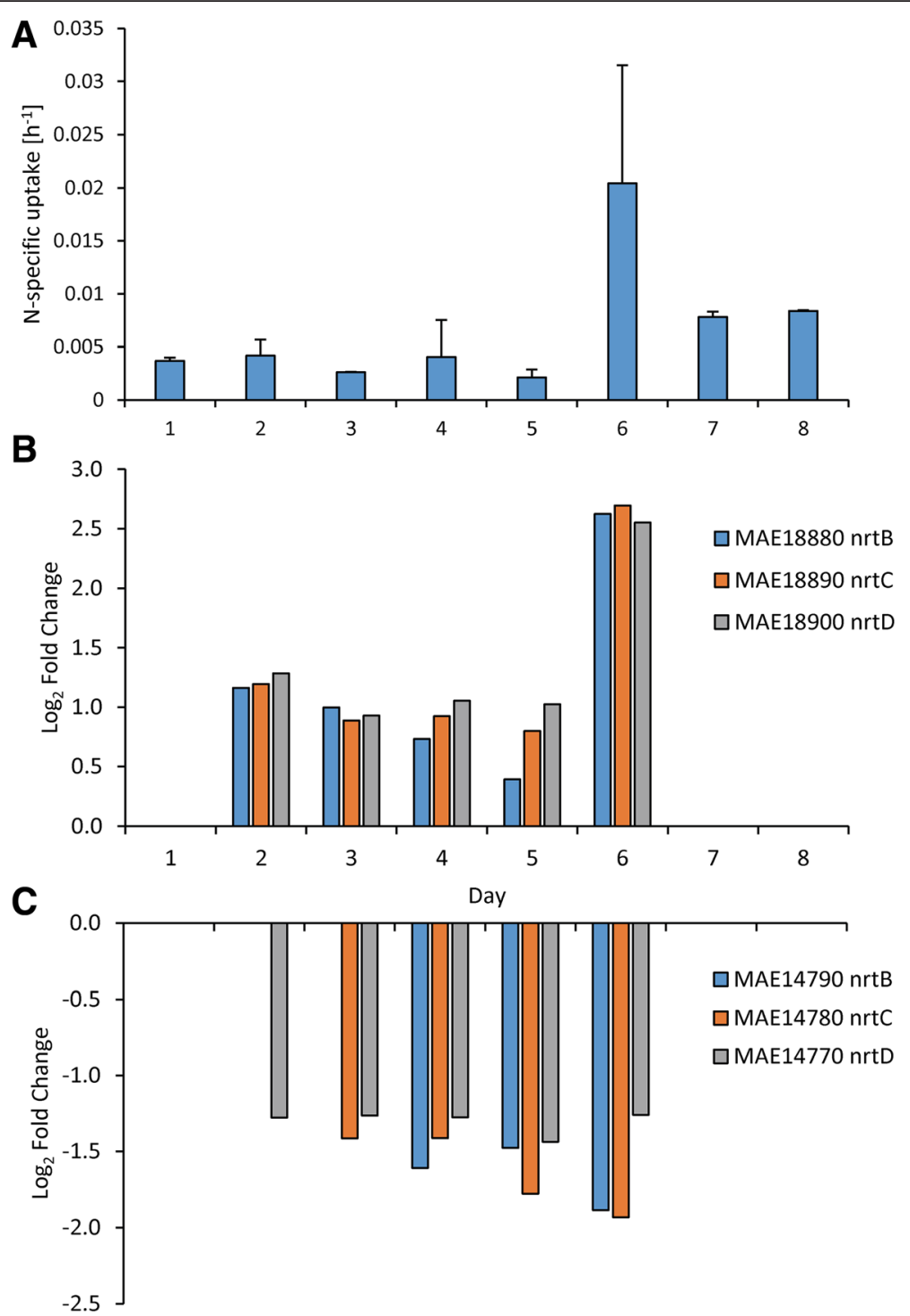

Fig. 6 Nitrate specific uptake rates and nitrate transporter gene expression patterns. Nitrate specific uptake rates (a) and gene expression of nitrate/nitrite transporters (b \& c) during the experiment. Error bars are the standard deviation between biological replicates $(n=3)$

later than photosynthesis genes upon $\mathrm{N}$ restoration. The continued need for $\mathrm{N}$ (continued upregulation of $\mathrm{N}$ transporters) likely reflects the continued cellular $\mathrm{N}$ demand during recovery from $\mathrm{N}$ limitation [56, 68]. Beyond photosynthetic and $\mathrm{N}$ transport and metabolism genes, other gene groups such as microcystin synthetase and lipid metabolism had individual genes that were no longer differentially expressed on days 6 and/or 7 indicating that there was not a universal transcriptional pattern in Microcystis as it recovered from $\mathrm{N}$-limitation and emphasizing the importance of a time series-based approach to fully understand physiological responses.

Uptake rates of individual nitrogenous compounds closely mirrored expression of $\mathrm{N}$-specific transporters during this study. As cells became more $\mathrm{N}$ starved, they preferentially and progressively increased uptake of ammonium and urea (Additional file 5: Figure S4) and upregulated the transcription of associated transporters (Figs. 7 and 8). Although uptake was not correlated with gene expression for ammonium and urea, upregulation of these transporters occurred and there was a $>4$-fold increase in ammonium and urea uptake rates. When nitrate was restored, ammonium and urea transporters returned to transcript levels similar to the control within $48 \mathrm{~h}$ and ammonium and urea uptake rates declined. In contrast, expression of some nitrate transporter genes and nitrate uptake rates were strongly correlated. During $\mathrm{N}$ starvation, expression of one nitrate transport gene set (nrtBCD, MAE18880, 18890, 18900) and uptake rates of nitrate remained static whereas restoration of nitrate 


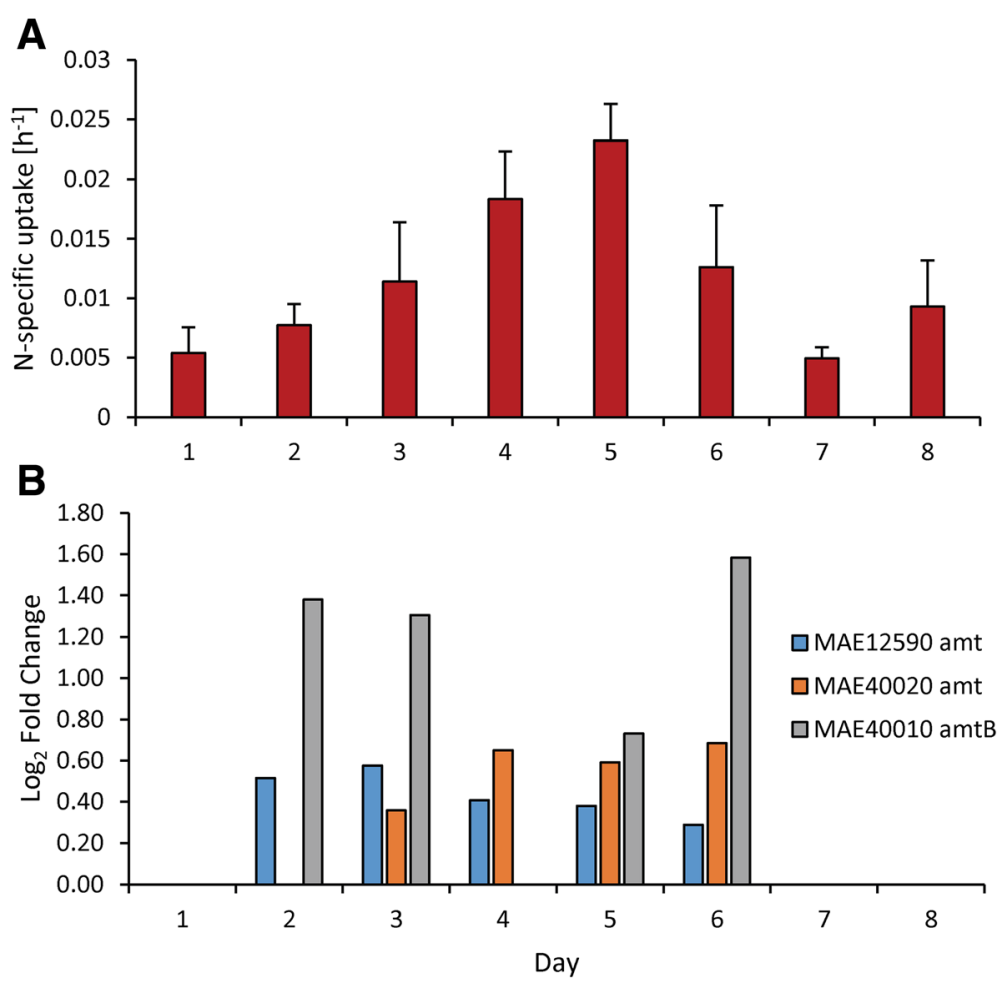

Fig. 7 Ammonium specific uptake rates and ammonium transporter gene expression patterns. Ammonium specific uptake rates (a) and gene expression of ammonium transporters (b) during the experiment. Error bars are the standard deviation between biological replicates $(n=3)$

was accompanied by the expression of genes for this nitrate transport gene set increasing 3 -fold and nitrate uptake rates increasing 6-fold. These suggest that $\mathrm{N}$ starved cells grown in the absence of nitrate preferentially assimilate reduced forms of $\mathrm{N}$ (ammonium and urea) until nitrate becomes available. These expression patterns differ from Synechocystis which, under N starvation, upregulated all $\mathrm{N}$ transporters (nitrate, ammonium, urea and amino acids) [30]. In contrast, Microcystis tailored its response more closely to available $\mathrm{N}$ supplies. When limited by $\mathrm{N}$, Microcystis turns on all $\mathrm{N}$ transporters but when one type of $\mathrm{N}$ is available (here nitrate), Microcystis increased production of the associated transporter, decreasing the production of other transporters (Figs. 6, 7 and 8). This contrasts with patterns of P-scavenging genes in Microcystis whose expression patterns were down- rather than upregulated when P-limited cultures were refed either inorganic or organic phosphorus [69].

During this study we believe we have identified high and low affinity nitrate transporters in Microcystis. During nitrogen limitation, one set of nitrate transporters (nrtBCD, MAE18880, 18890, 18900) was upregulated, correlating with nitrate uptake rates (Fig. 6a, b), while another set (nrtBCD, MAE14790, 14780, 14770) was downregulated (Fig. 6c). In our prior work [11], both sets of nitrate transporters were upregulated under nitrogen limitation (low $\mathrm{N}$ ), but the degree of upregulation varied with one set of transporters ( $n r t B C D$, MAE18880, 18890, 18900) having larger fold change values. In addition, in treatments in this study where there was higher concentrations of nitrate $(>2.5 \mu \mathrm{M})$, the transporter set MAE14790, 14780, 14770 had much higher fold change values (between 4.56 and 23.18) than MAE18880, 18890, 18900 (between 2.59 and 4.16). These expression patterns suggest differences in transport affinity with the high affinity transport set (active under N-limitation) represented by MAE18880, 18890, 18900 and the low affinity set (active under N-replete conditions) represented by MAE14790, 14780, 14770. The $n r t A B C D$ nitrate uptake system has been previously described as a high-affinity transport system in Synechococcus [70] and high-affinity and low-affinity nitrate transport systems have been described in higher plants [71] while multiple copies of nitrate transporters have been detected in marine phytoplankton [72]. However, this is the first documentation of the existence of potential differences in the functionality of nitrate uptake genes in Microcystis. Further study will be needed to definitively confirm how differences in expression patterns may be related to differences in affinity among these nitrate transporters.

To our knowledge, the relationship between the expression of transporter genes and the uptake of corresponding target compounds (as measured here via 


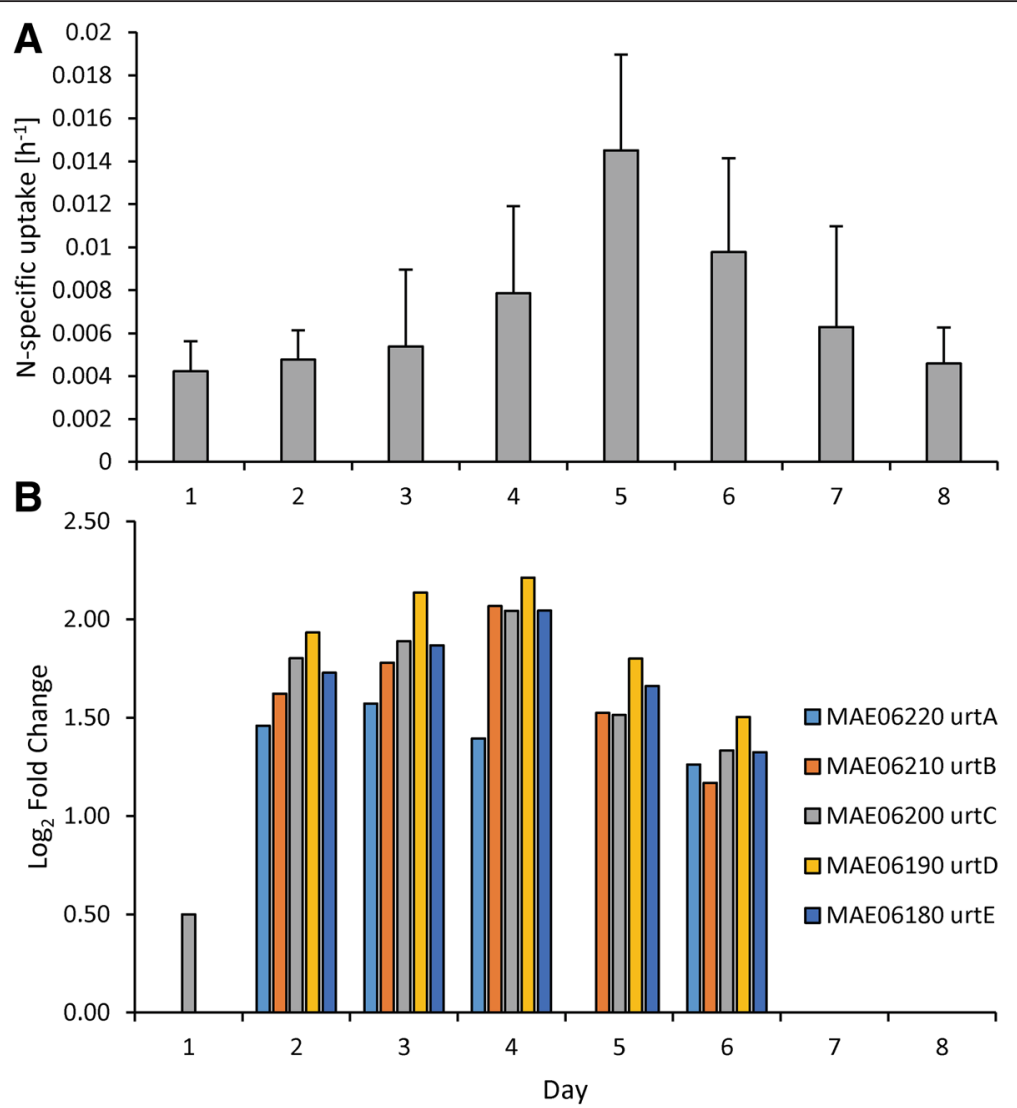

Fig. 8 Urea specific uptake rates and urea transporter gene expression patterns. Urea specific uptake rates (a) and gene expression of urea transporters (b) during the experiment. Error bars are the standard deviation between biological replicates $(n=3)$

isotopic tracers) has never been documented in cyanobacteria. Using a combined proteomic-transcriptomic approach, Wurch et al. [73] found that increased transcript abundance of P-transporter genes in a pelagophyte alga led to immediate increases in encoded transporter proteins. Cessation of gene expression, however, did not lead to an immediate reduction in transporter proteins suggesting that protein degradation can lag behind gene expression which is more responsive to environmental conditions [73]. During this study, after N was restored, $\mathrm{N}$ transporters took greater than $24 \mathrm{~h}$ to be downregulated and for $\mathrm{N}$ uptake rates to decline. Furthermore, since not all expression patterns correlate to uptake (in this study) or protein abundance [73], equating traditional cellular analyses of physiological state (such as APA, uptake, or $\left.F_{v} / F_{m}\right)$ to actual cellular status can be problematic. This illustrates the value of time course studies exploring gene expression and physiological responses as a means to provide detailed insight regarding the cellular physiology of microbes.

As cells become $\mathrm{N}$ limited, they must reduce their photosynthetic pigment inventory as metabolic capacity slows [51] in order to reduce excess energy and thereby avoid photo-damage [74]. In cyanobacteria, this is largely achieved via the degradation of phycobiliproteins as well as chlorophyll $a[20,51]$. The gene responsible for the breakdown of phycoblisomes, nblA (MAE02520), was upregulated during $\mathrm{N}$ deprivation (Fig. 4) and genes involved in the production of the various photosystems were downregulated (Fig. 4). In addition to preventing photo-damage, the breakdown of phycobiliproteins may also provide internal $\mathrm{N}$ and $\mathrm{C}$ sources, as these pigments can constitute $50 \%$ of soluble cellular protein in cyanobacteria $[51,75]$.

Beyond reduction of photosynthetic pigments, cyanobacteria must also tune their cellular $\mathrm{C}$ and $\mathrm{N}$ balance during $\mathrm{N}$ deprivation. Accordingly, numerous carbon concentrating mechanisms (ccm's) were downregulated along with a bicarbonate transport system under low $\mathrm{N}$ (bicA, sbtA, sbtB, and nhaS3) [49] and the uptake of bicarbonate was significantly correlated with the expression of these bicarbonate transport genes that were up and down regulated under high and low $\mathrm{N}$, respectively. These gene expression patterns have been observed in Synechocystis where many carbon concentrating mechanism genes were downregulated in response to $\mathrm{N}$ deprivation [30]. This reduction in uptake and expression of transport genes is likely due to a reduced need 


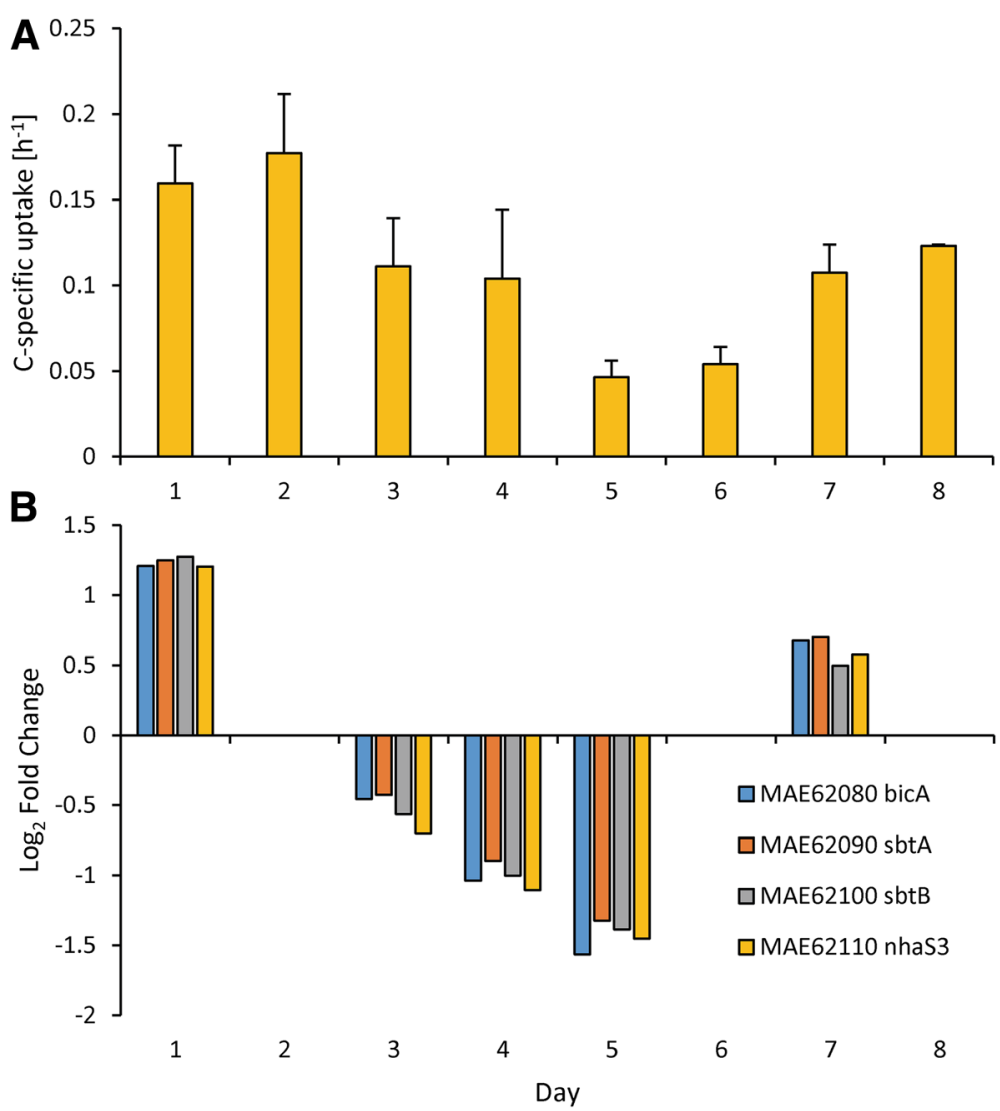

Fig. 9 Bicarbonate specific uptake rates and bicarbonate transporter gene expression patterns. Bicarbonate specific uptake rates (a) and gene expression of the bicarbonate transport system (b) during the experiment. Error bars are the standard deviation between biological replicates $(n=3)$

for cellular $\mathrm{C}$ due to lowered metabolism and photosynthesis as well as catabolism of internal stores of $\mathrm{C}$ from phycobiliproteins. In support of this hypothesis, the rate of inorganic carbon $\left(\mathrm{C}_{\mathrm{i}}\right)$ uptake has been found to be intimately linked with photosynthesis as PSI energy is thought to drive $\mathrm{C}_{\mathrm{i}}$ transport [76] and bicarbonate transport rates were strongly downregulated by $\mathrm{N}$ starvation during this study. Therefore, the degradation of the photosynthetic apparatus in response to $\mathrm{N}$ deprivation leads to reduction of carbon concentrating and uptake.

In addition to the above mentioned metabolic changes occurring due to fluctuating C:N balance during $\mathrm{N}$ deprivation, our prior work has shown that under low $\mathrm{N}$ conditions, Microcystis contains lower levels of microcystin and downregulates some genes within the microcystin synthetase $(m c y)$ cassette [11]. It was recently proposed that high C:N ratios will stimulate microcystin production and that an imbalance between 2-oxoglutarate (a compound intimately linked to maintaining $\mathrm{C}: \mathrm{N}$ balance in the cell) and ammonium regulates microcystin synthesis [77]. In the present study, as cells entered $\mathrm{N}$ limitation (high C:N ratio), the microcystin content of cultures significantly declined (by $50 \%$ ), mcy genes involved in tailoring and transport were upregulated (mcyHI)), genes involved in peptide synthesis were downregulated (mcyACDE), and some $m c y$ genes displayed no change relative to the control condition (mcyBFG; Fig. 5). These findings are generally consistent with prior studies where under $\mathrm{N}$ limitation, the $m c y A B C D E F$ genes were downregulated, with all but $m c y F$ being involved in peptide synthesis [11] suggesting that microcystin production relates more to $\mathrm{N}$ supply than C:N balance. Further, these changes in mcy transcript abundance suggest a partitioned response to $\mathrm{N}$ deprivation whereby genes involved in peptide synthesis are downregulated but genes involved in the tailoring and export of microcystin are upregulated. In addition, upon $\mathrm{N}$ restoration, transcripts of the $m c y C D E$ genes (involved in peptide synthesis) were restored to control levels and concentrations of microcystin increased by 2 -fold. The observed expression patterns demonstrate that all microcystin synthetase genes do not respond similarly to physiological changes within the cell and that the genes involved in peptide synthesis play a central role in modulating cellular microcystin content and are responsive to $\mathrm{N}$ availability. When exploring microcystin gene expression responses to environmental or physiological changes, 
most studies to date have focused on a single peptide synthesis gene (mcyA, B, D, or E) [78-84], an approach that does not provide a global view of microcystin synthesis. For example, had this study focused solely on $m c y B$ (as in Ginn et al. [82] and Beversdorf et al. [83]), we would have concluded there was no interaction with $\mathrm{N}$, as this gene was not differentially expressed during the experiment. Furthermore, time is a significant factor to consider as expression of each gene varied over time. Therefore, conclusions based on the expression of one peptide synthetase gene or a single time point may be biased by the response of the individual gene to environmental conditions or physiological cues.

Currently there are over 89 identified congeners of microcystin [85] and some strains of Microcystis are thought to incorporate different amino acids into the microcystin structure leading to changes in congener and relative toxicity [86]. Microcystis may also incorporate different amino acids during light and dark periods based upon amino acid availability that may alter the variant of microcystin synthesized [87]. Furthermore, microcystin is a N-rich compound, containing seven $\mathrm{N}$ atoms in its core ring with additional $\mathrm{N}$ in the variable $\mathrm{L}$-amino acid residues [88]. It is therefore an $\mathrm{N}$ expensive compound to produce. Production of this compound has been shown to decrease as cellular Nstores and the levels of exogenous $\mathrm{N}$ are reduced $(\mathrm{N}$ deprivation and starvation) $[5,14,15]$ and increase when $\mathrm{N}$ becomes available $[12,13,15]$. The upregulation of the two genes encoding tailoring enzymes ( $m y c I J)$ during $\mathrm{N}$ deprivation may reflect active modification of microcystin to different congeners. If this were true, it could have implications on overall toxicity $[89,90]$. However, the upregulation of these tailoring genes could also represent active disassembly of microcystin, perhaps in an effort to meet $\mathrm{N}$ demand during $\mathrm{N}$ deprivation. In this hypothesis, microcystin may act as an $\mathrm{N}$ reserve material to allow toxic strains to persist during times of $\mathrm{N}$ stress. Future work characterizing congener specific changes during $\mathrm{N}$ deprivation and/or investigations into the fate of microcystin may clarify this.

An understanding of the function of microcystin remains elusive, despite decades of research on this compound. There have been numerous theories relating the role of microcystin to quorum sensing, inhibition of competitors, managing oxidative stress, or grazing deterrence [87, 91-93] and it has been suggested that the compound is not essential for growth [94]. Three of these theories (quorum sensing, inhibition of competitors, or grazer deterrence) are each predicated upon the compound being actively exported from the cell and the $m c y H$ gene is thought to be involved in transport of microcystin outside the cell as it bears similarity to an ABC transporter [95].
Protein location prediction using PSORTb [96], however, predicts $m c y H$ is located within the inner membrane of the cell suggesting that $m c y H$ exports microcystin to the periplasmic space and not out of the cell. In support of this, Rohrlack and Hyenstrand [87] used a ${ }^{14} \mathrm{C}$ tracer to track the location and fate (either exported from the cell or metabolized) of microcystin under various light conditions and found no evidence of export or intracellular breakdown under these conditions. They did not, however, assess cultures under nutrient limitation, a condition which commonly occurs during blooms [6, 33, 97]. In the current study, the microcystin transporter $m c y H$ was upregulated under $\mathrm{N}$ limitation potentially supporting the hypothesis that microcystin is a quorum sensing compound as there were no grazers or competing algae present to induce an export response. However, there may also be internal cues triggering the export of microcystin, such as internal N-status or stress. If indeed cells are exporting microcystin during $\mathrm{N}$ limitation, this would be a counterintuitive response since, as mentioned earlier, microcystin is an $\mathrm{N}$-rich compound and cells would, in effect, be furthering their $\mathrm{N}$ limitation at a time of greatest need for the nutrient. Regardless, peptide synthesis genes were downregulated and concentrations of microcystin declined during $\mathrm{N}$ deprivation while transport and modification genes were upregulated, suggesting this compound may have an important extracellular function.

\section{Conclusions}

In summary, during $\mathrm{N}$ deprivation, Microcystis downregulated genes involved in photosynthesis, respiration, carbon acquisition, lipid metabolism, and amino acid biosynthesis while expression of genes relating to $\mathrm{N}$ acquisition and transport was upregulated. As $\mathrm{N}$ stress intensified, the response increased in both the strength of expression and number of genes. When $\mathrm{N}$ was restored, many of these responses reversed. Uptake of bicarbonate, nitrate, ammonium and urea generally paralleled expression of transporters for these compounds. Microcystis increased uptake and transcript abundance of transporters for ammonium and urea as cells became more $\mathrm{N}$ limited. When nitrate was restored, nitrate transporters were strongly upregulated and nitrate was assimilated at a high rate. Further, we have shown evidence that Microcystis has both a high and low affinity nitrate/nitrite uptake system as one gene set was upregulated and correlated with nitrate uptake while the other set was downregulated. Lastly, while concentrations of microcystin decreased during $\mathrm{N}$ deprivation and increased upon $\mathrm{N}$ restoration, the response of genes involved in the synthesis of this compound was more complex. Genes involved in peptide synthesis (mcyACDE) were downregulated during $\mathrm{N}$ 
deprivation whereas genes involved genes in tailoring and transport of microcystin (mcyHIJ) were upregulated, suggesting this compound could serve an external function under $\mathrm{N}$ stress. Collectively, this study highlights the complex choreography of gene expression, cell physiology, and toxin synthesis that dynamic $\mathrm{N}$ levels can elicit in this ecologically important cyanobacterium.

\section{Additional files}

Additional file 1: Table S1. Transcriptomic sequencing results. The number of sequenced reads that aligned to the Microcystis aeruginosa NIES-843 genome using Bowtie 2 within RSEM. Each treatment has three biological replicates. (DOC $93 \mathrm{~kb}$ )

Additional file 2: Figure S1. The number of differentially expressed genes in the low $\mathrm{N}$ experiment as compared to the control. Nitrogen refeed occurred on day 5 . Bars in the positive axis are those genes with increased transcript abundance and those in the negative access are genes with decreased transcript abundance. Solid bars are genes exhibiting $\log _{2}$ fold change values $>2$. (TIFF $226 \mathrm{~kb}$ )

Additional file 3: Figure S2. The number of genes differentially expressed (DE) for each time point of the experiment in each functional category (as defined by (yanoBase). Values in parenthesis next to the category name are the number of genes present in the category. (TIFF $303 \mathrm{~kb}$ )

Additional file 4: Figure S3. Heat map of gene expression of genes involved in fatty acid, phospholipid and sterol metabolism. Blue colors correspond to a decrease in transcript abundance while red colors correspond to an increase in transcript abundance. White colors denote no difference from the control condition. (TIFF $1761 \mathrm{~kb}$ )

Additional file 5: Figure S4. Nitrogen uptake of ${ }^{15} \mathrm{~N}$-labeled compounds as a percentage of total N uptake. (TIFF $115 \mathrm{~kb}$ )

\section{Competing interests}

The author's declare no competing interests.

\section{Authors' contributions}

$\mathrm{MJH}$ and CJG conceived and designed the experiments. MJH performed the experiments. MJH and CJG analyzed the data. CJG contributed reagents/materials/ analysis tools. MJH and CJG drafted, read, and approved the final manuscript.

\section{Acknowledgements}

We thank Jennifer Goleski, Andrew Griffith and Elizabeth Depasquale for assistance in sample analysis and conducting these experiments. This work was supported by the NOAA-ECOHAB program under award no. NA10NOS4780140 to Stony Brook University.

Received: 23 September 2015 Accepted: 3 December 2015

Published online: 16 December 2015

\section{References}

1. Hoagland P, Anderson DM, Kaoru Y, White AW. The economic effects of harmful algal blooms in the United States: Estimates, assessment issues, and information needs. Estuaries. 2002;25(4):819-37.

2. Carmichael W. A world overview - One-hundred-twenty-seven years of research on toxic cyanobacteria - Where do we go from here? In: Hudnell HK, editor. Cyanobacterial Harmful Algal Blooms: State of the Science and Research Needs. New York: Springer; 2008.

3. Carmichael WW. Health effects of toxin-producing cyanobacteria: "The CyanoHABs". Human Ecol Risk Assess. 2001;7(5):1393-407.

4. Watanabe MF, Oishi S. Effects of environmental factors on toxicity of a cyanobacterium (Microcystis aeruginosa) under culture conditions. Appl Environ Microbiol. 1985;49(5):1342-4.

5. Orr PT, Jones GJ. Relationship between microcystin production and cell division rates in nitrogen-limited Microcystis aeruginosa cultures. Limnol Oceanogr. 1998;43(7):1604-14.
6. Davis TW, Harke MJ, Marcoval MA, Goleski J, Orano-Dawson C, Berry DL, et al. Effects of nitrogenous compounds and phosphorus on the growth of toxic and non-toxic strains of Microcystis during cyanobacterial blooms. Aquat Microb Ecol. 2010;61:149-62.

7. Gobler CJ, Davis TW, Coyne KJ, Boyer GL. Interactive influences of nutrient loading, zooplankton grazing, and microcystin synthetase gene expression on cyanobacterial bloom dynamics in a eutrophic New York lake. Harmful Algae. 2007;6(1):119-33.

8. Moisander PH, Ochiai M, Lincoff A. Nutrient limitation of Microcystis aeruginosa in northern California Klamath River reservoirs. Harmful Algae. 2009;8:889-97.

9. Vézie C, Rapala J, Vaitomaa J, Seitsonen J, Sivonen K. Effect of nitrogen and phosphorus on growth of toxic and nontoxic Microcystis strains and on intracellular microcystin concentrations. Microb Ecol. 2002;43(4):443-54.

10. Yoshida M, Yoshida T, Takashima Y, Hosoda N, Hiroishi S. Dynamics of microcystin-producing and non-microcystin-producing Microcystis populations is correlated with nitrate concentration in a Japanese lake. FEMS Microbiol Lett. 2007;266(1):49-53.

11. Harke MJ, Gobler CJ. Global transcriptional responses of the toxic cyanobacterium, Microcystis aeruginosa, to nitrogen stress, phosphorus stress, and growth on organic matter. PLoS One. 2013;8(7), e69834.

12. Downing TG, Meyer C, Gehringer MM, van de Venter M. Microcystin content of Microcystis aeruginosa is modulated by nitrogen uptake rate relative to specific growth rate or carbon fixation rate. Environ Toxicol. 2005;20(3):257-62.

13. Van de Waal DB, Verspagen JMH, Lürling M, Donk EV, Visser PM, Huisman J. The ecological stoichiometry of toxins produced by harmful cyanobacteria: an experimental test of the carbon-nutrient balance hypothesis. Ecol Lett. 2009:12:1326-35.

14. Horst GP, Sarnelle O, White JD, Hamilton SK, Kaul RB, Bressie JD. Nitrogen availability increases the toxin quota of a harmful cyanobacterium, Microcystis aeruginosa. Water Res. 2014;54:188-98.

15. Van de Waal DB, Smith VH, Declerck SA, Stam EC, Elser JJ. Stoichiometric regulation of phytoplankton toxins. Ecol Lett. 2014;17(6):736-42.

16. Scott LL, Downing S, Phelan RR, Downing TG. Environmental modulation of microcystin and beta-N-methylamino-L-alanine as a function of nitrogen availability. Toxicon. 2014;87:1-5

17. Trimbee AM, Prepas EE. Evaluation of total phosphorus as a predictor of the relative biomass of blue-green-algae with emphasis on Alberta lakes. Can J Fish Aquat Sci. 1987;44(7):1337-42.

18. Watson SB, McCauley E, Downing JA. Patterns in phytoplankton taxonomic composition across temperate lakes of differing nutrient status. Limnol Oceanogr. 1997;42(3):487-95.

19. Flores $\mathrm{E}$, Herrero A. Nitrogen assimilation and nitrogen control in cyanobacteria. Biochem Soc Trans. 2005:33(1):164-7.

20. Collier JL, Grossman AR. Chlorosis induced by nutrient deprivation in Synechococcus sp. strain PCC 7942: not all bleaching is the same. J Bacteriol. 1992:174:4718-26.

21. Görl M, Sauer J, Baier T, Forchhammer K. Nitrogen-starvation-induced chlorosis in Synechococcus PCC 7942: adaptation to long-term survival. Microbiology. 1998;144(9):2449-58.

22. Aguirre von Wobeser E, Ibelings BW, Bok J, Krasikov V, Huisman J, Matthiis HC. Concerted changes in gene expression and cell physiology of the cyanobacterium Synechocystis sp. strain PCC 6803 during transitions between nitrogen and light-limited growth. Plant Physiol. 2011;155(3):1445-57.

23. Zinser ER, Lindell D, Johnson ZI, Futschik ME, Steglich C, Coleman ML, et al. Choreography of the transcriptome, photophysiology, and cell cycle of a minimal photoautotroph, Prochlorococcus. PLoS One. 2009;4(4), e5135.

24. Flaherty BL, Nieuwerburgh FV, Head SR, Golden JW. Directional RNA deep sequencing sheds new light on the transcriptional response of Anabaena sp. strain PCC 7120 to combinded-nitrogen deprivation. BMC Genomics. 2011;12:332

25. Ludwig M, Bryant DA. Acclimation of the global transcriptome of the cyanobacterium Synechococcus sp. strain PCC7002 to nutrient limitations and different nitrogen sources. Front Microbiol. 2011;3:1-15.

26. Moustafa A, Evans AN, Kulis DM, Hackett JD, Erdner DL, Anderson DM, et al. Transcriptome profiling of a toxic dinoflagellate reveals a gene-rich protist and a potential impact on gene expression due to bacterial presence. PLoS One. 2011;5(3):1-10.

27. Hackett JD, Wisecaver JH, Brosnahan ML, Kulis DM, Anderson DM, Bhattacharya D, et al. Evolution of saxitoxin synthesis in cyanobacteria and dinoflagellates. Mol Biol Evol. 2013;30(1):70-8. 
28. Penn K, Wang J, Fernando SC, Thompson JR. Secondary metabolite gene expression and interplay of bacterial functions in a tropical freshwater cyanobacterial bloom. ISME J. 2014;8(9):1866-78.

29. Steffen MM, Dearth SP, Dill BD, Li Z, Larsen KM, Campagna SR, et al. Nutrients drive transcriptional changes that maintain metabolic homeostasis but alter genome architecture in Microcystis. ISME J. 2014;8(10):2080-92.

30. Krasikov V, Aguirre von Wobeser E, Dekker HL, Huisman J, Matthijs HC. Time-series resolution of gradual nitrogen starvation and its impact on photosynthesis in the cyanobacterium Synechocystis PCC 6803. Physiol Plant. 2012;145(3):426-39.

31. Brittain SM, Wang J, Babcock-Jackson L, Carmichael WW, Rinehart KL, Culver DA. Isolation and characterization of microcystins, cyclic heptapeptide hepatotoxins from a Lake Erie strain of Microcystis aeruginosa. J Gt Lakes Res. 2000;26(3):241-9.

32. Straub C, Quillardet P, Vergalli J, de Marsac NT, Humbert J-F. A day in the life of Microcystis aeruginosa strain PCC 7806 as revealed by a transcriptomic analysis. PLoS One. 2011;6(1), e16208.

33. Chaffin JD, Bridgeman TB, Heckathorn SA, Mishra S. Assessment of Microcystis growth rate potential and nutrient status across a trophic gradient in western Lake Erie. J Gt Lakes Res. 2011;37(1):92-100.

34. Jones MN. Nitrate reduction by shaking with cadmium: alternative to cadmium columns. Water Res. 1984;18:643-6.

35. Parsons TR, Maita Y, Lalli CM. A manual of chemical and biological methods for seawater analysis. Oxford: Pergamon Press; 1984.

36. Valderrama JC. The simultaneous analysis of total nitrogen and phosphorus in natural waters. Mar Chem. 1981;10:109-22.

37. Price NM, Harrison PJ. Comparison of methods for the analysis of dissolved urea in seawater. Mar Biol. 1987;94:307-17.

38. Fischer WJ, Garthwaite I, Miles CO, Ross KM, Aggen JB, Chamberlin AR, et al. Congener-independent immunoassay for microcystins and nodularins. Environ Sci Technol. 2001;35(24):4849-56.

39. Mulholland MR, Gobler CJ, Lee C. Peptide hydrolysis, amino acid oxidation, and nitrogen uptake in communities seasonally dominated by Aureococcus anophagefferens. Limnol Oceanogr. 2002:47(4):1094-108.

40. Orcutt KM, Lipschultz F, Gundersen K, Arimoto R, Michaels AF, Knap AH, et al. A seasonal study of the significance of N2 fixation by Trichodesmium spp. at the Bermuda Atlantic Time-series Study (BATS) site. Deep Sea Res Pt II. 2001:48(8-9):1583-608.

41. Gilbert PM, Lipschultz F, McCarthy JJ, Altabet MA. Isotope dilution models of uptake and remineralization of ammonium by marine plankton. Limnol Oceanogr. 1982;27(4):630-50

42. Ilikchyan IN, McKay RML, Zehr JP, Dyhrman ST, Bullerjahn GS. Detection and expression of the phosphonate transporter gene phnD in marine and freshwater picocyanobacteria. Environ Microbiol. 2009;11(5):1314-24.

43. Bolger AM, Lohse M, Usadel B. Trimmomatic: a flexible trimmer for Illumina sequence data. Bioinformatics. 2014;30(15):2114-20.

44. Kaneko T, Nakajima N, Okamoto S, Suzuki I, Tanabe Y, Tamaoki M, et al. Complete genomic structure of the bloom-forming toxic cyanobacterium Microcystis aeruginosa NIES-843. DNA Res. 2007;14(6):247-56.

45. Li B, Dewey CN. RSEM: accurate transcript quantification from RNA-Seq data with or without a reference genome. BMC Bioinformatics. 2011;12(232):232.

46. Langmead B, Salzberg SL. Fast gapped-read alignment with Bowtie 2. Nat Methods. 2012;9(4):357-9.

47. Leng N, Dawson JA, Thomson JA, Ruotti V, Rissman Al, Smits BMG, et al. EBSeq: an empirical Bayes hierarchical model for inference in RNA-seq experiments. Bioinformatics. 2013;29(16):2073.

48. Wass MN, Barton G, Sternberg MJ. CombFunc: predicting protein function using heterogeneous data sources. Nucleic Acids Res. 2012;40(Web Server issue):W466-470

49. Sandrini G, Matthijs HC, Verspagen JM, Muyzer G, Huisman J. Genetic diversity of inorganic carbon uptake systems causes variation in $\mathrm{CO} 2$ response of the cyanobacterium Microcystis. ISME J. 2014;8(3):589-600.

50. Allen MM, Smith AJ. Nitrogen chlorosis in blue-green algae. Arch Mikrobiol. 1969:69:114-20

51. Schwarz R, Forchhammer K. Acclimation of unicellular cyanobacteria to macronutrient deficiency: emergence of a complex network of cellular responses. Microbiology. 2005;151(Pt 8):2503-14.

52. Fadi Aldehni M, Sauer J, Spielhaupter C, Schmid R, Forchhammer K. Signal transduction protein PII is required for NtcA-regulated gene expression during nitrogen deprivation in the cyanobacterium Synechococcus elongatus strain PCC 7942. J Bacteriol. 2003;185(8):2582-91.
53. Allen MM. Cyanobacterial cell inclusions. Annu Rev Microbiol. 1984;38:1-25.

54. Collier JL, Grossman AR. A small polypeptide triggers complete degradation of light-harvesting phycobiliproteins in nutrient-deprived cyanobacteria. EMBO J. 1994;13(5):1039-47.

55. Baier K, Nicklisch S, Grundner C, Reinecke J, Lockau W. Expression of two nblA-homologous genes is required for phycobilisome degradation in nitrogen-starved Synechocystis sp. PCC6803. FEMS Microbiol Lett. 2001; 195(1):35-9.

56. Allen MM, Hutchison F. Nitrogen limitation and recovery in the cyanobacterium Aphanocapsa 6308. Arch Microbiol. 1980;128(1):1-7.

57. Van de Waal DB, Ferreruela G, Tonk L, Van Donk E, Huisman J, Visser PM, et al. Pulsed nitrogen supply induces dynamic changes in the amino acid composition and microcystin production of the harmful cyanobacterium Planktothrix agardhii. FEMS Microbiol Ecol. 2010;74(2): 430-8.

58. Mackerras AH, de Chazal NM, Smith GD. Transient accumulations of cyanophycin in Anabaena cylindrica and Synechocystis 6308. J Gen Microbiol. 1990;136(10):2057-65.

59. Guschina IA, Harwood JL. Algal lipids and effect of the environment on their biochemistry. In: Arts MT, Brett MT, Kainz M, editors. Lipids in Aquatic Ecosystems. New York: Springer; 2009. p. 1-24.

60. Singh SC, Sinha RP, Häder D-P. Role of lipids and fatty acids in stress tolerance in cyanobacteria. Acta Protozool. 2002:41:297-308.

61. de Loura IC, Dubacq JP, Thomas JC. The effects of nitrogen deficiency on pigments and lipids of cyanobacteria. Plant Physiol. 1987;83(4):838-43.

62. Piorreck M, Pohl P. Formation of biomass, total protein, chlorophylls, lipids and fatty acids in green and blue-green algae during one growth phase. Phytochemistry. 1984;23(2):217-23.

63. Kumar Saha S, Uma L, Subramanian G. Nitrogen stress induced changes in the marine cyanobacterium Oscillatoria willei BDU 130511. FEMS Microbiol Ecol. 2003;45(3):263-72.

64. Stevens Jr SE, Balkwill DL, Paone DAM. The effects of nitrogen limitation on the ultrastructure of the cyanobacterium Agmenellum quadruplicatum. Arch Mikrobiol. 1981;130:204-12.

65. Osumi T, Nishino T, Katsuki H. Studies on the $\Delta 5$-Desaturation in Ergosterol biosynthesis in yeast. J Biochem. 1979;85(3):819-26.

66. Volkman JK. Sterols in microorganisms. Appl Microbiol Biotechnol. 2003; 60(5):495-506.

67. Merida I, Avila-Flores A, Merino E. Diacylglycerol kinases: at the hub of cell signalling. Biochem J. 2008:409(1):1-18.

68. Tapia MI, de Alda JAGO, Llama MJ, Serra JL. Changes in intracellular amino acids and organic acids induced by nitrogen starvation and nitrate or ammonium resupply in the cyanobacterium Phormidium laminosum. Planta. 1996;198(4):526-31.

69. Harke MJ, Berry DL, Ammerman JW, Gobler CJ. Molecular response of the bloom-forming cyanobacterium, Microcystis aeruginosa, to phosphorus limitation. Microb Ecol. 2012;63:188-98.

70. Omata $T$, Andriesse $X$, Hirano A. Identification and characterization of a gene cluster involved in nitrate transport in the cyanobacterium Synechococcus sp. PCC7942. Mol Gen Genet. 1993;236-236(2-3):193-202.

71. Galván A, Fernández E. Eukaryotic nitrate and nitrite transporters. Cell Mol Life Sci. 2001;58(2):225-33.

72. Song B, Ward BB. Molecular cloning and characterization of highaffinity nitrate transporters in marine phytoplankton. J Phycol. 2007; 43(3):542-52.

73. Wurch LL, Haley ST, Orchard ED, Gobler CJ, Dyhrman ST. Nutrient-regulated transcriptional responses in the brown tide-forming alga Aureococcus anophagefferens. Environ Microbiol. 2011;13(2):468-81.

74. Salomon E, Bar-Eyal L, Sharon S, Keren N. Balancing photosynthetic electron flow is critical for cyanobacterial acclimation to nitrogen limitation. Biochim Biophys Acta. 2013;1827(3):340-7.

75. DeRuyter YS, Fromme P. Molecular Structure of the Photosynthetic Apparatus. In: The Cyanobacteria, Molecular Biology, Genomics and Evolution. Herrero A, Flores E, editors. Norfolk: Caister Academic Press; 2008. p. 217-70.

76. Kaplan A, Schwarz R, Lieman-Hurwitz J, Reinhold L. Physiological and molecular aspects of the inorganic carbon-concentrating mechanism in cyanobacteria. Plant Physiol. 1991;97(3):851-5.

77. Beversdorf $\sqcup$, Miller TR, McMahon KD. Long-term monitoring reveals carbon-nitrogen metabolism key to microcystin production in eutrophic lakes. Front Microbiol. 2015;6:456. 
78. Rinta-Kanto JM, Ouellette AJA, Boyer GL, Twiss MR, Bridgeman TB, Wilhelm SW. Quantification of toxic Microcystis spp. during the 2003 and 2004 blooms in western Lake Erie using quantitative real-time PCR. Environ Sci Technol. 2005:39(11):4198-205.

79. Hotto AM, Satchwell MF, Berry DL, Gobler CJ, Boyer GL. Spatial and temporal diversity of microcystins and microcystin-producing genotypes in Oneida Lake, NY. Harmful Algae. 2008;7(5):671-81.

80. Sevilla E, Martin-Luna B, Vela L, Bes MT, Fillat MF, Peleato ML. Iron availability affects mcyD expression and microcystin-LR synthesis in Microcystis aeruginosa PCC7806. Environ Microbiol. 2008;10(10):2476-83.

81. El Semary NA. Investigating factors affecting growth and cellular mcyB transcripts of Microcystis aeruginosa PCC 7806 using real-time PCR. Ann Microbiol. 2010;60(2):181-8.

82. Ginn HP, Pearson LA, Neilan BA. NtcA from Microcystis aeruginosa PCC 7806 is autoregulatory and binds to the microcystin promoter. Appl Environ Microbiol. 2010;76(13):4362-8.

83. Beversdorf $L$, Miller TR, McMahon KD. The role of nitrogen fixation in cyanobacterial bloom toxicity in a temperate, eutrophic lake. PLoS One. 2013;8(2), e56103.

84. Pimentel JS, Giani A. Microcystin production and regulation under nutrient stress conditions in toxic Microcystis strains. Appl Environ Microbiol. 2014; 80(18):5836-43.

85. Welker M, von Dohren H. Cyanobacterial peptides - nature's own combinatorial biosynthesis. FEMS Microbiol Rev. 2006;30(4):530-63.

86. Dittmann E, Borner T. Genetic contributions to the risk assessment of microcystin in the environment. Toxicol Appl Pharmacol. 2005;203(3):192-200.

87. Rohrlack T, Hyenstrand P. Fate of intracellular microcystins in the cyanobacterium Microcystis aeruginosa (Chroococcales, Cyanophyceae). Phycologia. 2007;46(3):277-83.

88. Tillett D, Dittmann E, Erhard M, Döhren H, Börner T, Neilan BA. Structural organization of microcystin biosynthesis in Microcystis aeruginosa PCC7806: an integrated peptide-polyketide synthetase system. Chem Biol. 2000;7:753-64.

89. Rinehart KL, Namikoshi M, Choi BW. Structure and biosynthesis of toxins from blue-green algae (cyanobacteria). J Appl Phycol. 1994;6(2):159-76.

90. Rinehart KL, Harada K, Namikoshi M, Chen C, Harvis CA, Munro MHG, et al. Nodularin, microcystin, and the configuration of Adda. J Am Chem Soc. 1988;110(25):8557-8.

91. Dittmann E, Erhard M, Kaebernick M, Scheler C, Neilan BA, von Döhren H, et al. Altered expression of two light-dependent genes in a microcystinlacking mutant of Microcystis aeruginosa PCC 7806. Microbiology. 2001; 147(11):3113-9.

92. Zilliges Y, Kehr JC, Meissner S, Ishida K, Mikkat S, Hagemann M, et al. The cyanobacterial hepatotoxin microcystin binds to proteins and increases the fitness of Microcystis under oxidative stress conditions. PLoS One. 2011;6(3), e17615.

93. Meissner S, Steinhauser D, Dittmann E. Metabolomic analysis indicates a pivotal role of the hepatotoxin microcystin in high light adaptation of Microcystis. Environ Microbiol. 2015:17(5):1497-509.

94. Hesse K, Dittmann E, Börner T. Consequences of impaired microcystin production for light-dependent growth and pigmentation of Microcystis aeruginosa PCC 7806. FEMS Microbiol Ecol. 2001;37:39-43.

95. Pearson LA, Hisbergues M, Borner T, Dittmann E, Neilan BA. Inactivation of an $A B C$ transporter gene, $\mathrm{mcyH}$, results in loss of microcystin production in the cyanobacterium Microcystis aeruginosa PCC 7806. Appl Environ Microbiol. 2004;70(11):6370-8.

96. Yu NY, Wagner JR, Laird MR, Melli G, Rey S, Lo R, et al. PSORTb 3.0: improved protein subcellular localization prediction with refined localization subcategories and predictive capabilities for all prokaryotes. Bioinformatics. 2010;26(13):1608-15.

97. Anderson DM, Glibert PM, Burkholder JM. Harmful algal blooms and eutrophication: nutrient sources, composition, and consequences. Estuaries. 2002;25(4):704-26.

\section{Submit your next manuscript to BioMed Central and we will help you at every step:}

- We accept pre-submission inquiries

- Our selector tool helps you to find the most relevant journal

- We provide round the clock customer support

- Convenient online submission

- Thorough peer review

- Inclusion in PubMed and all major indexing services

- Maximum visibility for your research

Submit your manuscript at www.biomedcentral.com/submit
Biomed Central 